\title{
Traditional Irrigation Practices, High Crop Diversification and Multiple Agricultural Cycles in Wastewater Irrigation Farming in Peru Urban Areas, Zambia
}

\author{
Evaristo Mwaba Kapungwe ${ }^{1}$ \\ ${ }^{1}$ Geography Department, University of Zambia, Lusaka, Zambia \\ Correspondence: Evaristo Mwaba Kapungwe, Geography Department, University of Zambia, Lusaka, Zambia. \\ Tel: xxx. Email: ekapungwe@unza.zm
}

Received: August 14, 2013 Accepted: November 8, 2013 Online Published: November 22, 2013

doi:10.5539/jgg.v5n4p106 URL: http://dx.doi.org/10.5539/jgg.v5n4p106

\begin{abstract}
Studies conducted on peri urban wastewater irrigation agriculture in Zambia have not adequately tackled issues pertaining to farmer managed irrigation systems in heavy metal contaminated wastewater irrigation farming. The study focused on characteristics of farmer managed irrigation systems in wastewater irrigation farming contaminated with heavy metals at New Farm in Mufulira and Chilumba Gardens in Kafue. The study objectives were: (i) to ascertain the nature of irrigation practices and types of crops grown at the two study sites in Zambia. (ii) to determine the nature of agricultural cycles in wastewater irrigated areas. It was hypothesised that: (i) the nature of irrigation practices and types of crops were not significantly different at the two study sites in different seasons. (ii) the agro-ecological factors did not significantly influence the nature of irrigation practices and types of crops. The method comprised observation of sources of water supply, methods of irrigation and types of crops grown coupled with agro-ecological factors such as soil, slope and drainage at field plots located at regular intervals along transects established in the stratified sampling zones. The results indicated that farmer managed irrigation systems at the two study sites were characterised by multiple sources of water supply, multiple methods of irrigation, relatively high number of crops per study site equivalent to twenty types of crops grown per study site and relatively high number of crops per field plot ranging from one crop to ten crops per field plot coupled with multiple cycles of agricultural practices. The nature of irrigation practices and types of crops were influenced by a combination of agro-ecological factors. In conclusion, the farmer managed irrigation systems in wastewater irrigation farming were characterised by traditional irrigation practices, high crop diversification and multiple cycles of agricultural practices which were typical of traditional farmer managed irrigation systems. It can be argued that the crop cultivators have adapted the rural traditional irrigation systems' practices to the peri urban wastewater irrigation systems in Zambia which confirmed the findings from other studies in developing countries. The study findings will be used to select and implement appropriate agricultural practices which can mitigate the negative effects of heavy metal contamination.
\end{abstract}

Keywords: traditional irrigation practices, high crop diversification, agricultural cycles, heavy metal contamination, wastewater irrigation farming, peri urban areas, Zambia

\section{Introduction}

The wastewater use for livelihood activities in urban and peri-urban areas is a reality that planners and policy makers must face in developing countries (Smit \& Nasr, 1992; Buechler et al., 2002b). The opportunities of wastewater cultivation in developing countries include increased food production in places where there is lack of clean water; supply of food to urban population, improvement of living standards of crop cultivators through consumption of crops and income generation through selling of crops coupled with recycling of nutrients from wastewater as fertilizers (Raschid-Sally \& Jayakody, 2008; Faruqui, 2002; Duque, 2002). Some of the challenges associated with wastewater irrigation farming in developing countries include inadequate policies, legislations and institutions dealing with the use of wastewater in crop production (Buechler at al., 2002a, b; Parkinson \& Tayler, 2003). There is lack of alternative cheaper or safer water sources and some areas were irrigated with heavy metal polluted wastewater (Raschid-Sally \& Jayakody, 2008; Buechler et al., 2002a, Cavallini \& Young, 2002; Silva-Ochoa \& Scott, 2002; Smith et al., 2001; Dreschel et al., 2011).There is inadequate infrastructure for conveyance of wastewater to cultivated fields such that the farmers located far away 
from main wastewater channel do not adequately access wastewater (Ali, 2002). In certain instances farmers vandalised sewage infrastructure in order to obtain the waste for irrigation of crops. Furthermore, the infrastructure in farmer managed irrigation systems in wastewater irrigation farming do not entirely conform to the standard technical hydraulic structure engineering designs (Parajuli, 1999; Ali, 2002).

Previous studies conducted on peri urban wastewater irrigation agriculture in Zambia revealed heavy metal contamination of wastewater, soils and crops; traditional land management practices; multiple cropping systems and potential health risks associated with consumption of heavy metal contaminated food crops (Kapungwe, 2011,2012 ; 2013). Nevertheless, there is inadequate research on farmer managed irrigation systems with regard to irrigation practices and agricultural cycles in wastewater irrigated areas contaminated with heavy metals in Zambia. The study focused on the characteristics of farmer managed irrigation systems in wastewater irrigation farming contaminated with heavy metals at two peri urban areas in Zambia. The results from this study would be compared to findings from previous studies conducted by Kapungwe $(2011,2012,2013)$ on wastewater irrigation in Zambia and other developing countries (Bradford et al., 2002; Bradford et al., 2003). The study objectives were: (i) to ascertain the nature of irrigation practices and types of crops grown at the two study sites. (ii) to determine the nature of agricultural cycles in wastewater irrigated areas. It was hypothesised that: (i) the nature of irrigation practices and types of crops were not significantly different at the two study sites in different seasons. (ii) the agro-ecological factors did not significantly influence the nature of irrigation practices and types of crops grown at the study sites. The study findings will be used to select and implement appropriate irrigation farming practices which can mitigate the negative effects of heavy metal contamination

\subsection{Theoretical Framework}

Although the typologies of farming systems have been developed for the rural farming systems, there is inadequate information on typologies of urban production farming systems. The urban production farming systems range from haphazard, under-managed, low production systems to high-input systems with considerable use of fertilizer and pesticides coupled with well-organised and reliable irrigation system (de Neergaard et al., 2009). Many urban production farming systems rely on recycled waste from both household or animal production and wastewater due to either the absence of a clean water source or presence of nutrient content (de Neergaard et al., 2009). The increasing competition for limited water resources has resulted in a tendency for farming communities to use wastewater for irrigation in urban and peri-urban areas. According to the study by Obuobie et al., (2003) in urban and peri urban agriculture in Accra of Ghana the farmers used wastewater to irrigate crops in the household gardens which took place in and around home, open space farming which took place on lands located some distance from human dwellings and in share cropping systems in peri urban areas. The general agronomic practices developed in the rural farming systems can be adapted to the urban production systems due to the often small and adaptive nature of urban production systems (de Neergaard et al., 2009). In Africa there are many different urban crop production systems which are influenced by limited space, high land values, close proximity to markets, uncertain land tenure, theft, vandalism, high value of crops, proximity to homestead of farmers, size of plots, commercial or subsistence, nature and quantity of input; cropping patterns availability of labour and water (de Neergaard et al., 2009; Olouch et al., 2009). However, there is an urgent need for a robust and usable typology of urban production system which takes into consideration a range of agronomic innovations and practices that have been developed under varying conditions (de Neergaard et al., 2009).

This study used the traditional rural farmer managed irrigation systems as a theoretical framework to analyse variables pertaining to wastewater irrigation farming systems in peri urban areas in Zambia. The traditional rural farmer managed irrigation systems infrastructures are shaped by socio-economic, managerial and environmental factors beside technical consideration (Uphoff, 1986; Ali, 2002). The managerial domains (Uphoff, 1986) comprise:

i. watershed domain includes catchment characteristics, agro-climatology, river regime which determine the amount of water availability at the source.

ii. agricultural domain includes the crops, soil and land features which determine the technical requirements of irrigation water.

iii. water supply domain includes the irrigation systems infrastructure which facilitate the deliverance, conveyance and deliverance of water to land or crop

Therefore, the traditional rural farmer managed irrigation systems are socio-technical systems adapted to the local environment such as agroecological conditions (Uphoff, 1986). The studies conducted on indigenous irrigation systems in Nepal indicated that agro ecological conditions influenced the irrigation technology while 
appropriate institutional arrangements were needed to manage irrigation infrastructure in rural traditional farmer-managed irrigation systems (Parajuli, 1999). The above mentioned facts can be applied to the peri urban wastewater irrigation farming in developing countries. It can be argued that it is likely the urban farmers have adapted the rural traditional farmer managed irrigation systems practices to wastewater irrigation farming systems in peri urban areas in developing countries including Zambia because the relevant authorities do not render financial and technical support to wastewater irrigation farming systems as it is regarded as an illegal and informal activity (Bradford et al., 2002; Bradford et al., 2003).

\section{Study Methods}

\subsection{Location of Study Sites}

Two study sites were selected in the peri-urban areas located in Mufulira in the Copperbelt Province and Kafue in the Lusaka Province, Zambia (Figure 1). The New Farm study site in Mufulira is located along the Kansuswa River adjacent to Kantanshi Stabilization Ponds in the triangle shaped area between the Kansuswa River and tailing dams (Figure 2). The Chilumba Gardens study site in Kafue is located along Kasenje and Shikoswe Rivers in the Kafue Estate Industrial area between Zambia and Soloboni Compounds behind Nitrogen Chemicals of Zambia (Figure 3).

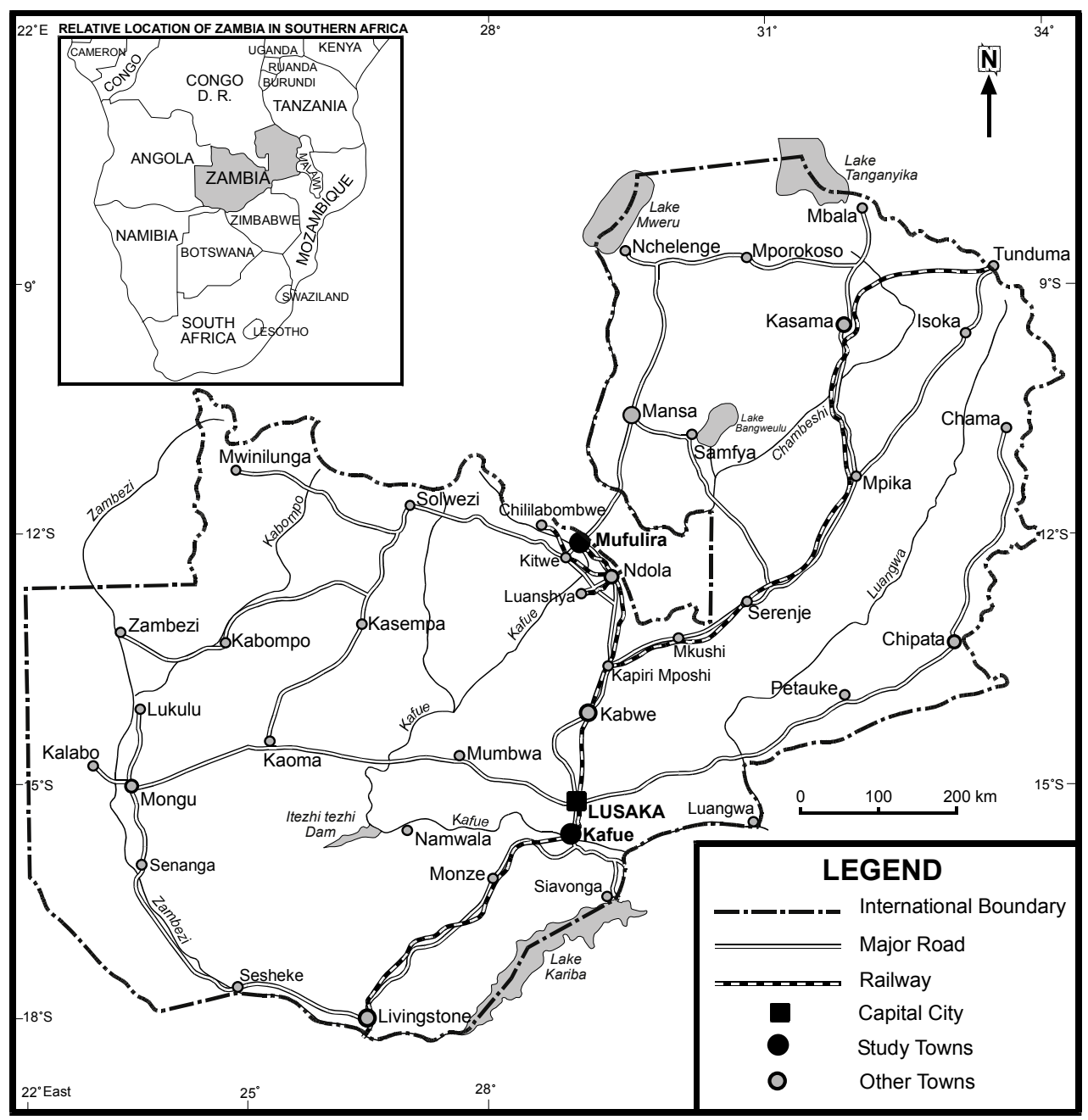

Figure 1. Map of Zambia showing the study towns of Mufulira and Kafue (Kapungwe, 2011) 


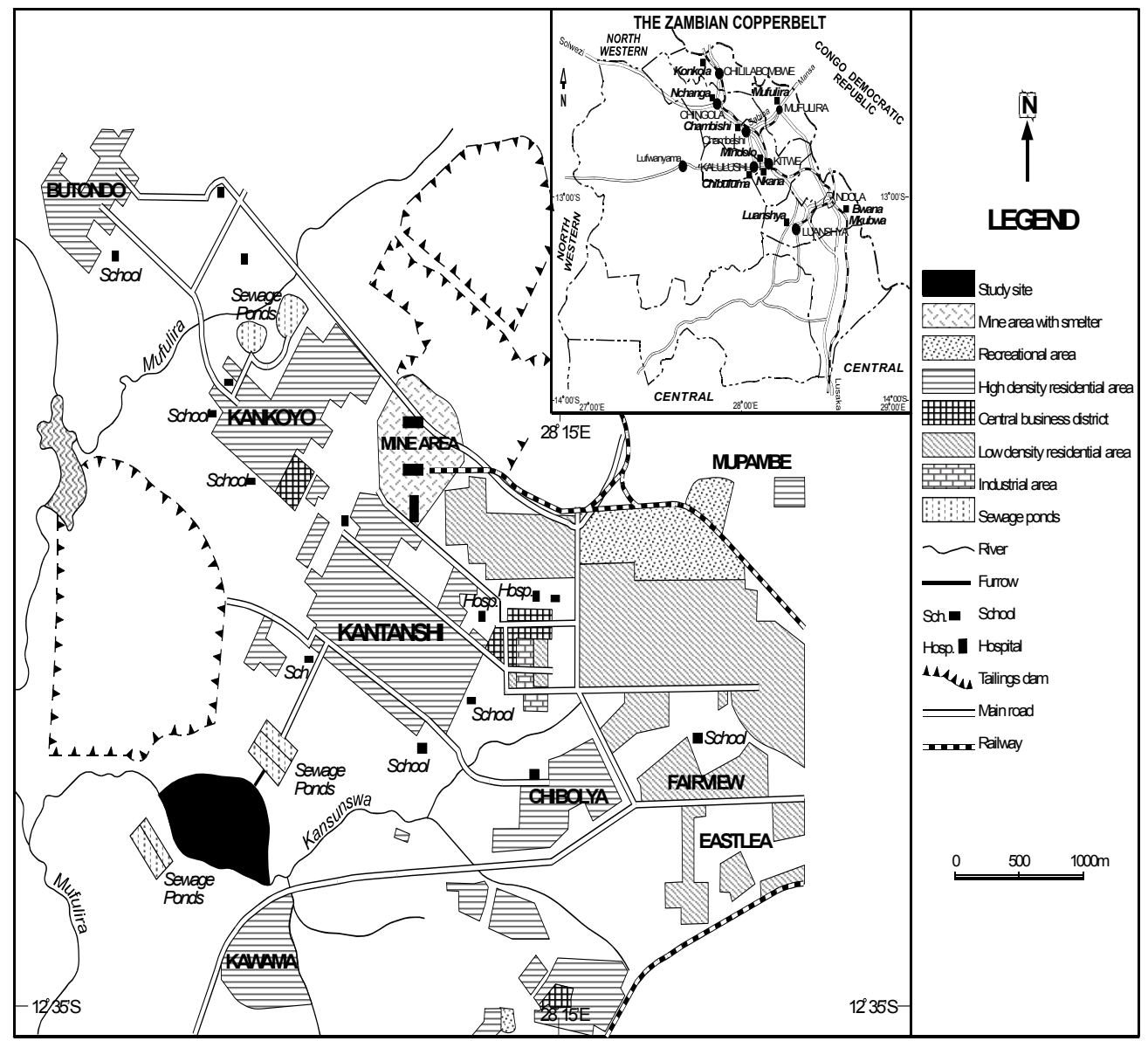

Figure 2. Location of New Farm study site in Mufulira (Adapted from Kapungwe, 2011)

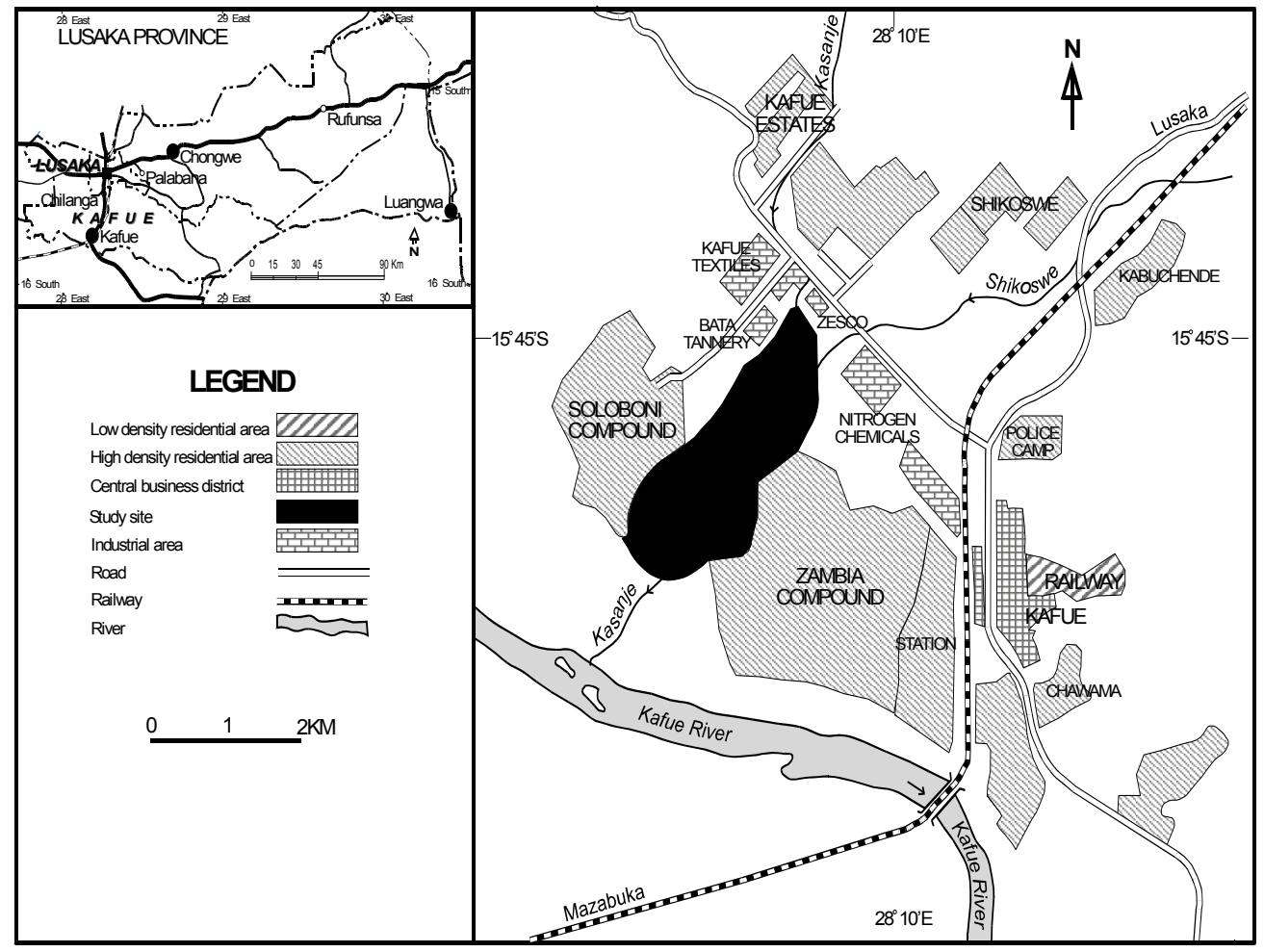

Figure 3. Location of Chilumba Gardens study site in Kafue (Adapted from Kapungwe, 2011) 


\subsection{Description of Study Site}

The climate at study sites is typical tropical savanna with three distinct seasons namely hot wet season from November to March, cool dry season from April to July and hot dry season from August to October with the mean annual rainfall of 900 to $1000 \mathrm{~mm}$ per year (Kapungwe, 2011). The study sites experienced heavy metal contamination of wastewater (Table 1), soils and crops (Kapungwe, 2011, 2012, 2013). The characteristics of the salient features at the study sites are summarised in Table 2.

The community based organisations formed by the crop cultivators were namely Kansuswa Peasant Farmers' Association at New Farm in Mufulira and Chilumba Peasant Farmers Association at Chilumba Gardens in Kafue (Table 3). The associations have been formally registered with Registrar of Societies and issued with Certificates of registration. The aims of the associations included improving crop production; reduction of poverty among the crop cultivators and improving marketing of the food crops. There were guidelines, rules and regulations, which governed the operation of the associations. The association membership was drawn from the crop cultivators at New Farm and Chilumba Gardens. Currently, the total membership was estimate at 150 crop cultivators in New Farm area whilst the total membership was estimated at 1200 crop cultivators in Chilumba Garden area. The farmers' association worked closely with Resident Development Committees and other stakeholders.

Table 1 . Heavy metals $(\mathrm{mg} / \mathrm{l})$ in waste water at the two study sites

\begin{tabular}{|c|c|c|c|c|c|c|}
\hline Seasons & $\begin{array}{c}\text { No. of } \\
\text { samples }\end{array}$ & $\begin{array}{c}\text { Copper } \\
(\mathrm{Mean} \pm \mathrm{SE})\end{array}$ & $\begin{array}{c}\text { Lead } \\
(\mathrm{Mean} \pm \mathrm{SE})\end{array}$ & $\begin{array}{c}\text { Cobalt } \\
(\mathrm{Mean} \pm \mathrm{SE})\end{array}$ & $\begin{array}{l}\text { Chromium } \\
(\text { Mean } \pm \text { SE) }\end{array}$ & $\begin{array}{c}\text { Nickel } \\
(\mathrm{Mean} \pm \mathrm{SE})\end{array}$ \\
\hline \multicolumn{7}{|c|}{ New Farm study site in Mufulira } \\
\hline Hot wet: Nov-Mar & 13 & $0.08 \pm 0.02$ & $0.02 \pm 0.01$ & ND & ND & $0.03 \pm 0.01$ \\
\hline Cool dry: Apr-Jul & 7 & $0.04 \pm 0.02$ & $0.36 \pm 0.25$ & $0.03 \pm 0.01$ & $0.05 \pm 0.02$ & ND \\
\hline Hot dry: Aug-Oct & 12 & $0.53 \pm 0.17 *$ & $0.02 \pm 0.01$ & ND & $0.18 \pm 0.07 *$ & $0.01 \pm 0.00$ \\
\hline \multicolumn{7}{|c|}{ Chilumba Gardens study site in Kafue } \\
\hline Hot wet: Nov-Mar & 12 & $0.01 \pm 0.02$ & $0.03 \pm 0.01$ & $0.03 \pm 0.02$ & ND & $0.06 \pm 0.01$ \\
\hline Cool dry: Apr-Jul & 19 & $0.06 \pm 0.01$ & $0.71 \pm 0.33$ & $0.09 \pm 0.02 *$ & $0.21 \pm 0.05$ & $0.37 \pm 0.17 *$ \\
\hline Hot dry: Aug-Oct & 13 & $0.23 \pm 0.04 *$ & $0.08 \pm 0.04$ & ND & $0.33 \pm 0.09 *$ & $0.12 \pm 0.02$ \\
\hline \multicolumn{2}{|c|}{${ }^{\mathrm{a}} \mathrm{FAO}$ Heavy metal acceptable limits } & 0.2 & $\mathbf{5 . 0}$ & 0.05 & 0.1 & 0.2 \\
\hline
\end{tabular}

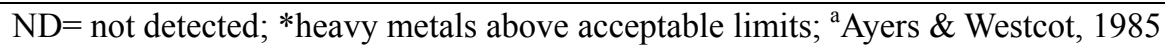

Source: Kapungwe, 2011, 2012, 2013.

Table 2. Summary of characteristics of the salient features at the two study sites

\begin{tabular}{|c|c|c|}
\hline \multirow{2}{*}{$\begin{array}{l}\text { Characteristics } \\
\text { Study towns } \\
\end{array}$} & \multicolumn{2}{|c|}{ Study sites } \\
\hline & Mufulira in Copperbelt province & Kafue in Lusaka Province \\
\hline Name of study sites & New Farm & Chilumba Gardens \\
\hline Type of irrigation systems & Mid-hill & River Valley \\
\hline Quantity of water supply & Hill amount/large quantity & High amount/ large quantity \\
\hline Types of cropping systems & Multiple cropping systems & Multiple cropping systems \\
\hline Types of land management practices & Traditional land management & Traditional land management \\
\hline Number of cultivated fields & 300 field plots & 2100 field plots \\
\hline Types of wastewater & Primary treated domestic sewage & Untreated Industrial wastewater \\
\hline $\begin{array}{l}\text { Heavy metals which contaminated } \\
\text { wastewater }\end{array}$ & Copper, cobalt, chromium & Copper, cobalt, chromium, nickel \\
\hline Heavy metals which contaminated soils & Copper & Heavy metals within acceptable limits \\
\hline Heavy metals which crops & Copper, lead, chromium, nickel & Copper, lead, chromium, nickel \\
\hline \multirow[t]{4}{*}{ Heavy metal contaminated crops } & Pumpkin leaves & Chinese cabbage \\
\hline & Tomato fruits & Pumpkin leaves \\
\hline & Swiss chard leaves & Sweet potato leaves \\
\hline & Okra fruits & Tomato fruits \\
\hline
\end{tabular}

Sources: Field data, 2006, 2007; Kapungwe, 2011; 2012; 2013. 
Table 3. Characteristics of Farmers' Association at the study sites

\begin{tabular}{|c|c|c|}
\hline Characteristics & \multicolumn{2}{|c|}{ Study sites } \\
\hline \multirow[t]{2}{*}{ Name of study sites } & Kansuswa & Chilumba \\
\hline & $\begin{array}{l}\text { Association at New Farm in } \\
\text { Mufulira }\end{array}$ & $\begin{array}{l}\text { Association at Chilumba Gardens } \\
\text { in Kafue }\end{array}$ \\
\hline \multirow[t]{2}{*}{ Registration } & Registered with Registrar of & Registered with Registrar of \\
\hline & $\begin{array}{l}\text { Societies and issued with certificate } \\
\text { of registration }\end{array}$ & $\begin{array}{l}\text { Societies and issued with certificate } \\
\text { of registration }\end{array}$ \\
\hline Executive committee & Existing: stable and functional & Existing: stable and functional \\
\hline Constitution & Existing and functional constitution & Existing and functional constitution \\
\hline Membership & 150-200 members & 900-1200 members \\
\hline Selected activities & $\begin{array}{l}\text { Proportional sharing of water, } \\
\text { resolve land use conflicts }\end{array}$ & $\begin{array}{l}\text { Resolve the land use conflicts } \\
\text { proportional sharing of water }\end{array}$ \\
\hline
\end{tabular}

Source: Field data, 2005.

\subsection{Stratification of Wastewater Irrigation Areas in to Sampling Zones.}

Study areas were stratified into sampling zones. The strata at New Farm study site included Kansuswa, Extension and Copperbelt Energy Corporation Zones (Figure 4) whilst the strata at Chilumba Gardens study site included Kasenje, Shikoswe and Nitrogen Chemical of Zambia Zones (Figure 5).The zoning of the areas was based on the physical land characteristics comprising slope, type of soils and drainage. The summary of the physical land characteristics of sampling zones are shown in Table 4.

Table 4. Summary of physical land characteristics of sampling zones at two study sites

\begin{tabular}{|c|c|c|c|}
\hline $\begin{array}{l}\text { Physical land } \\
\text { characteristics }\end{array}$ & & Sampling zones & \\
\hline \multicolumn{4}{|c|}{ New Farm study site } \\
\hline Stratum & Kansuswa stream & Extension & $\begin{array}{l}\text { Copperbelt } \\
\text { Corporation (CEC) } \\
\text { line }\end{array}$ \\
\hline Slope & $\begin{array}{l}\text { Flat land slope }\left(0-5^{\circ}\right) \\
\text { gentle slope }\left(6-10^{\circ}\right)\end{array}$ & Gentle slope $\left(6-10^{\circ}\right)$ & Gentle slope $\left(6-10^{\circ}\right)$ \\
\hline Soil & $\begin{array}{l}\text { Red, laterite, stony soils to dark } \\
\text { brown, clay loam soils }\end{array}$ & $\begin{array}{l}\text { Red laterite, stony } \\
\text { soils to brownish clay } \\
\text { loam soils }\end{array}$ & $\begin{array}{l}\text { Laterite stony soil, clay } \\
\text { loam, reddish brown soil }\end{array}$ \\
\hline Drainage & $\begin{array}{l}\text { Moderate drainage to } \\
\text { Poor drainage }\end{array}$ & $\begin{array}{lr}\text { Poor } & \text { drainage, } \\
\text { seepage, } & \text { moderate } \\
\text { drainage, } & \text { good } \\
\text { drainage } & \end{array}$ & Moderate drainage \\
\hline \multicolumn{4}{|c|}{ Chilumba Gardens study site } \\
\hline Stratum & $\begin{array}{l}\text { Nitrogen Chemical of Zambia } \\
\text { (NCZ) waste disposal sites }\end{array}$ & Kasenje River & Shikoswe River \\
\hline Slope & $\begin{array}{l}\text { Flat land }\left(0-5^{\circ}\right) \\
\text { Gentle slope }\left(6-10^{\circ}\right) \\
\text { Steep slope }\left(11-15^{\circ}\right)\end{array}$ & $\begin{array}{l}\text { Gentle slope }\left(6-10^{\circ}\right) \\
\text { Steep slope }\left(11-15^{\circ}\right)\end{array}$ & $\begin{array}{l}\text { Flat land }\left(0-5^{\circ}\right) \\
\text { Gentle slope }\left(6-10^{\circ}\right) \\
\text { Steep slope }\left(11-15^{\circ}\right)\end{array}$ \\
\hline Soil & Black coal ash, sandy loam soils & $\begin{array}{l}\text { Clay loam soils, } \\
\text { sandy loam soils. }\end{array}$ & $\begin{array}{l}\text { Clay soils, slippery, } \\
\text { muddy, sandy loamy }\end{array}$ \\
\hline Drainage & $\begin{array}{l}\text { Good/high /adequate drainage, } \\
\text { Moderate/ mild/limited drainage, } \\
\text { Poor/low/inadequate drainage, } \\
\text { water logged areas }\end{array}$ & $\begin{array}{l}\text { High drainage, } \\
\text { Mild drainage, } \\
\text { Low drainage, } \\
\text { water logged areas }\end{array}$ & $\begin{array}{l}\text { High/adequate drainage } \\
\text { Mild/limited drainage, } \\
\text { Low/inadequate drainage, } \\
\text { water logged, } \\
\text { stagnant water }\end{array}$ \\
\hline
\end{tabular}

Source: Field data, 2006, 2007, Kapungwe, 2012 


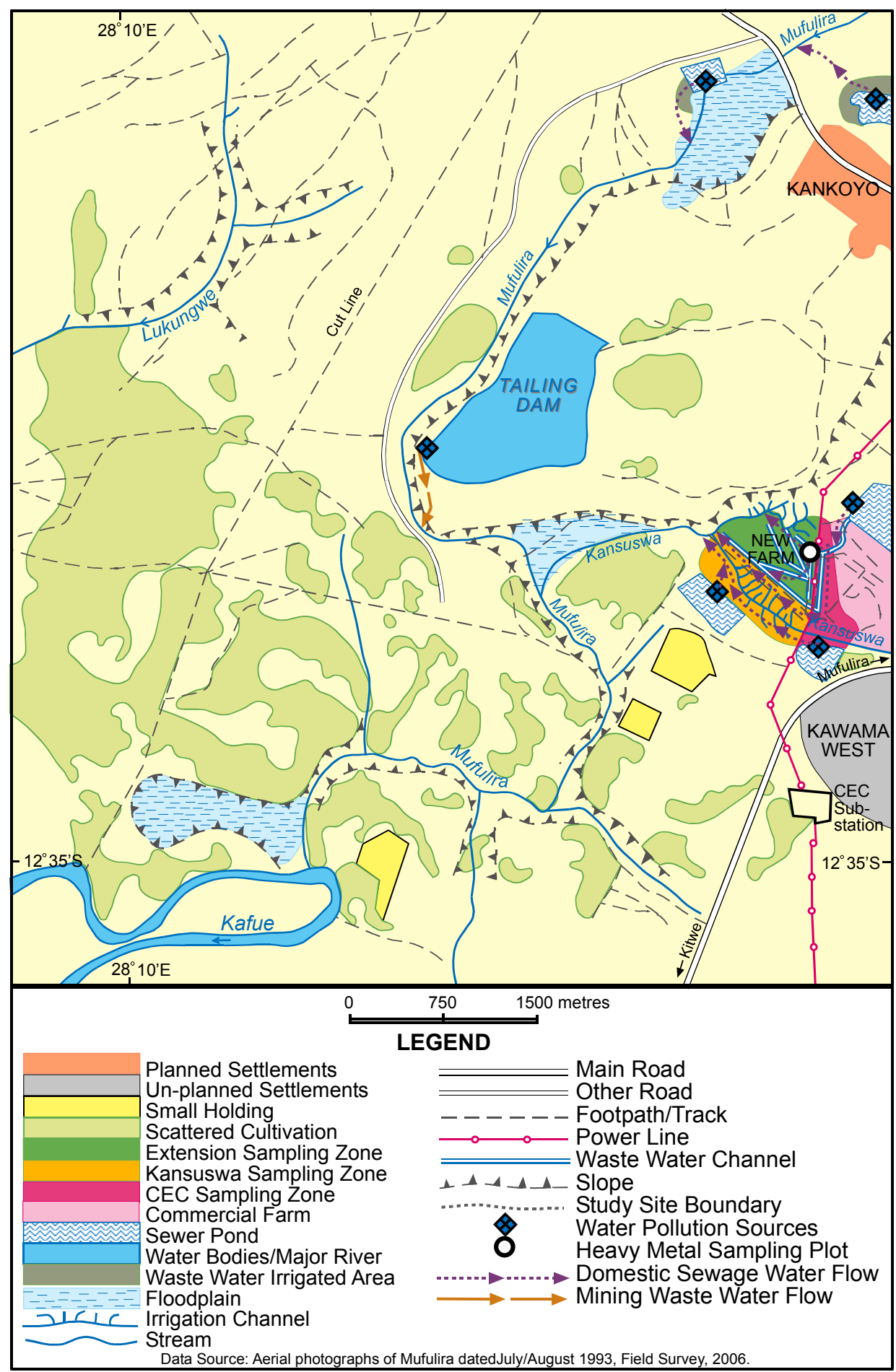

Figure 4. Sampling zones at New Farm in Mufulira (Adapted from Kapungwe, 2011, 2012, 2013) 


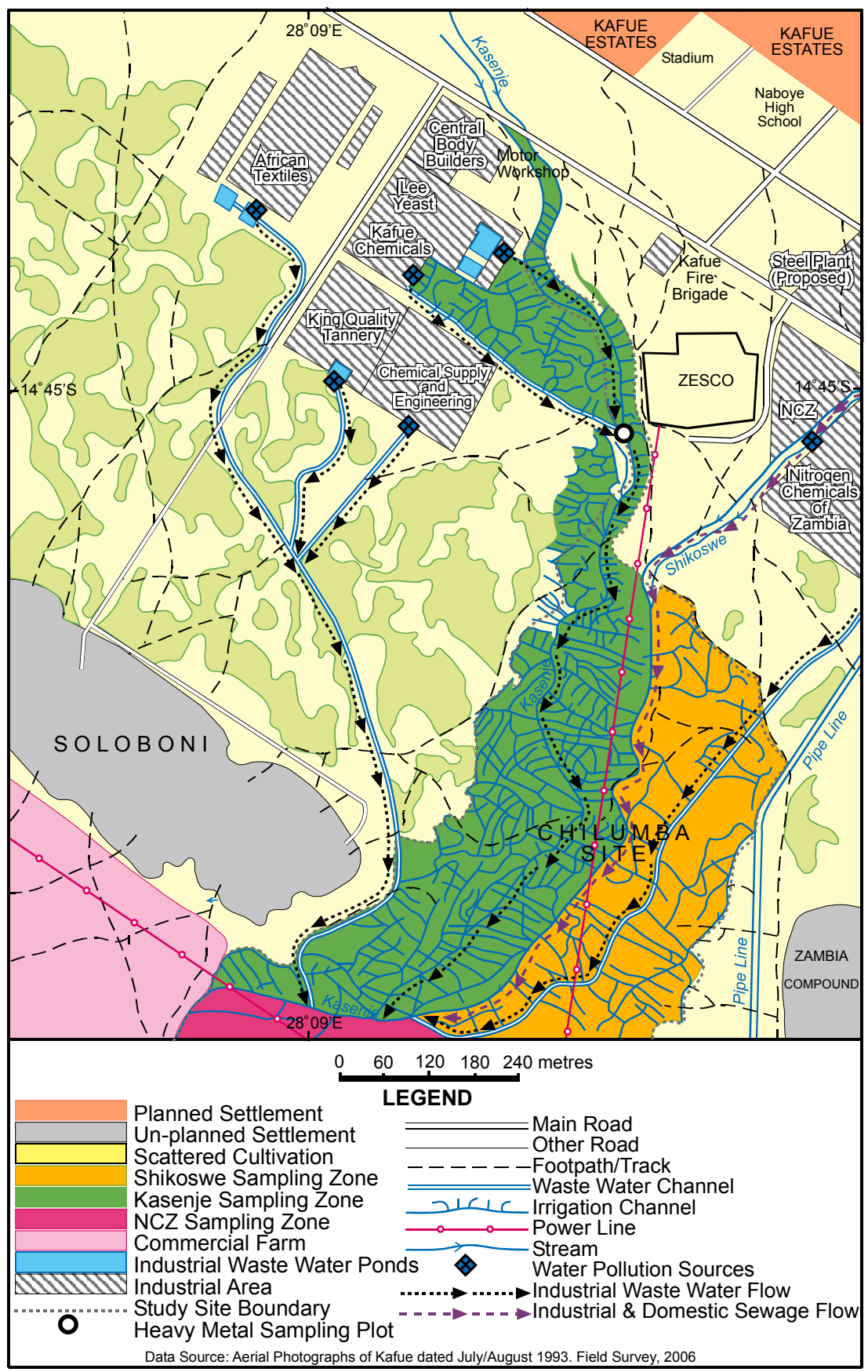

Figure 5. Sampling zones at Chilumba Gardens in Kafue (Adapted from Kapungwe, 2011, 2012, 2013)

\subsection{Establishment of Transects in the Strata}

Longitudinal transects were established in each zone along rivers, footpath, tracks, roads and main irrigation furrows which were accessible by either foot or vehicle. A total of twenty three transects were established in the strata comprising eight longitudinal transects at New Farm and fifteen longitudinal transects at Chilumba Gardens(Table 5). The length of transects ranged from 200 to 1200 metres.

\subsection{Sampling and Observation of Irrigation Practices and Crops in Field Plots}

The field plots were sampled monthly between February, 2006 and January, 2007 (Table 6). Field plots were selected at a regular interval of 100 paces $(1$ pace $\approx 1$ meter) along permanent longitudinal transect with a start at a beginning of each transect. The field plots were observed in order to collect information on different variables pertaining to sources of water supply, methods of irrigation, types of crops grown and the agro ecological factors such slope, soils and drainage. A total of two field plots were observed on each observation point. The range of 
observation at each point was 20 meters radius around each observation point. In other words at each sampling points two fields were observed which were located on both sides of the traversed transect. A cumulative total of 1111 fields were observed at New Farm in Mufulira and 2148 fields were observed at Chilumba Garden in Kafue (Table 7).

Table 5. Sampling strata and transects at two study sites

\begin{tabular}{|c|c|c|}
\hline Strata & Transects & $\begin{array}{l}\text { Length of transects } \\
\text { Mean } \pm \text { SE (meters) }\end{array}$ \\
\hline \multicolumn{3}{|c|}{ New Farm study site in Mufulira } \\
\hline \multirow[t]{2}{*}{ Kansuswa River Zone } & Transect one (1) & $682.82 \pm 46.13$ \\
\hline & Transect two (2) & $690.91 \pm 41.46$ \\
\hline \multirow{5}{*}{ Extension Zone } & Transect one (1) & $658.33 \pm 31.28$ \\
\hline & Transect two (2) & $200.0 \pm 0.00$ \\
\hline & Transect three (3) & $637.5 \pm 26.16$ \\
\hline & Transect four (4) & $330.0 \pm 15.28$ \\
\hline & Transect five (5) & $666.67 \pm 21.08$ \\
\hline Copperbelt Energy Corporation & Transect one (1) & $990.91 \pm 45.64$ \\
\hline \multicolumn{3}{|c|}{ Chilumba Gardens study site in Kafue } \\
\hline \multirow{5}{*}{ Kasenje River Zone } & Transect one (1) & $342.86 \pm 42.71$ \\
\hline & Transect two (2) & $970.0 \pm 33.50$ \\
\hline & Transect three (3) & $650.0 \pm 28.78$ \\
\hline & Transect four (4) & $787.5 \pm 51.54$ \\
\hline & Transect five (5) & $850.0 \pm 133.63$ \\
\hline \multirow{5}{*}{ Shikoswe River Zone } & Transect one (1) & $209.09 \pm 9.09$ \\
\hline & Transect two (2) & $654.55 \pm 194.65$ \\
\hline & Transect three (3) & $550.0 \pm 46.29$ \\
\hline & Transect four (4) & $490.91 \pm 41.46$ \\
\hline & Transect five (5) & $1044.44 \pm 220.55$ \\
\hline \multirow{5}{*}{ Nitrogen Chemicals of Zambia Zone } & Transect one (1) & $100.0 \pm 0.00$ \\
\hline & Transect two (2) & $1000.0 \pm 29.81$ \\
\hline & Transect three (3) & $775.0 \pm 31.34$ \\
\hline & Transect four (4) & $1010.0 \pm 80.90$ \\
\hline & Transect five (5) & $1157.14 \pm 59.04$ \\
\hline
\end{tabular}

Source: Field data, 2006-2007.

Table 6. Monthly sampled field plots at two study sites

\begin{tabular}{ccccc}
\hline Population of field plots & Months & New Farm & Chilumba Gardens & Total \\
\hline Target population & & 300 & 2100 & 2400 \\
\hline & February, 2006 & 57 & 48 & 105 \\
& March,2006 & 38 & 100 & 164 \\
& April,2006 & 51 & 155 & 151 \\
& May,2006 & 81 & 197 & 236 \\
Sampled population & June,2006 & 94 & 80 & 291 \\
& July,2006 & 116 & 245 & 196 \\
& August,2006 & 118 & 287 & 363 \\
& September,2006 & 86 & 235 & 373 \\
& October, 2006 & 112 & 227 & 347 \\
Total cumulative & November, 2006 & 116 & 223 & 343 \\
& December, 2006 & 158 & 225 & 381 \\
Source & January, 2007 & 84 & $\mathbf{2 1 4 8}$ & 309 \\
\hline
\end{tabular}

Source: Field data, 2006-2007. 
Table 7. Field plots sampled in different sampling zones at two study sites

\begin{tabular}{ccc}
\hline Sampling land zones/stratum & Number of fields & Percentage \\
\hline Sampling zones at & Chilumba Gardens & \\
Shikoswe stream & 606 & 18.6 \\
Kasenje stream & 698 & 21.4 \\
Nitrogen Chemicals of Zambia lagoons & 844 & 25.9 \\
Sub total & $\mathbf{2 1 4 8}$ & $\mathbf{1 0 0 . 0}$ \\
Sampling zones at New Farm & \\
Kansuswa stream & 333 & 10.2 \\
Copperbelt Energy Corporation & 230 & 7.1 \\
Extension & 548 & 16.8 \\
Sub Total & $\mathbf{1 1 1 1}$ & $\mathbf{1 0 0 . 0}$ \\
\hline
\end{tabular}

Source: Field data, 2006-2007.

\subsection{Data Analysis}

The relative percentages were calculated for data collected on nature of irrigation practices and types of crops grown at the two study sites. The cumulative percentages were summarised in $100 \%$ stacked column charts which compared percentage each value contributed to a total across categories of sources of water supply, methods of irrigation and types of crop grown at the two study sites. Hypotheses were tested using two tailed Chi-square test at the 0.05 significance level. The crop diversification was calculated based on the number of types of crops grown per study site and the number of types of crops grown per field plot. In other words, relative abundance of crops per field plot and study site was used as an indicator of crop diversification. The monthly farming practices observed for a full year were summarised in the circular graphs and seasonal calendar tables in order to ascertain the cycles of agricultural activities.

\section{Results and Discussion}

\subsection{Traditional Irrigation Practices}

The results on the sources of water supply at the two study sites shown in Figure 6 and Figure 7 indicated multiple sources of water supply were used to irrigate crops. The sources of water supply included rainfall, domestic sewage wastewater from Sewage Stabilization Ponds (Figure 8 and Figure 9), industrial wastewater from factories in the Kafue Industrial Area., shallow wells, seepage, river water without wastewater and river water mixed with wastewater such as Lee Yeast Factory effluents discharged into Kasenje River (Figure 10). The types of wastewater used to irrigate crops were significantly different at the two study sites $\left(\chi^{2}=23.73, \mathrm{df}=1, \mathrm{P}\right.$ $\leq 0.05$; two tailed). This study indentified that the domestic sewage $(62.9 \%)$ was dominantly used to irrigate crops at New Farm while industrial wastewater (51.2\%) was dominantly used at Chilumba Gardens. The wastewater mixed with river water $(10.0 \%)$ was recorded only at Chilumba Garden. The probable reasons for multiple sources of water supply at the two study sites include:

i. physical land characteristics differences: For instances seepage was the source of water supply in land with poor drainage especially on the marginal edge of the dambos which were water logged areas while the shallow wells were sources of water in land with good drainage

ii. the perennial rivers such as the Shikowe and Kasenje Rivers which discharges river water into catchment areas

iii. seasonal variations which influenced the amount of water availability from different sources. For instance rainfall was the main source of water supply in the wet season while the wastewater was the main sources of water in the dry seasons

iv. socio economic activities which generated different types of wastewater such as domestic sewage generated from residential areas in Mufulira and industrial effluents generated from the factory processes in Kafue Industrial Area in Kafue(Kapungwe, 2011, 2013).

v. inadequate institutional arrangements which culminated into formulation of inadequate mechanism of sharing of water resources among the crop cultivators such that some of the farmers located near wastewater channels occasionally denied other farmers access to wastewater (Ali, 2002).

This study indicated that wastewater was dominantly used to irrigate crops at the two study sites. Nevertheless, the results from the previous studies by Kapungwe $(2011,2012 ; 2013)$ indicated that the wastewater was 
contaminated with heavy metals at the two study sites which culminated into heavy metal contamination of soil and crops (Kapungwe, 2011, 2013). Occasionally the water from shallow wells, seepage and river water without wastewater allegedly not contaminated with heavy metals was used to irrigated crops. From the foregoing explanation it can be argued that there were inadequate safer water sources and wastewater irrigated areas were irrigated with heavy metal polluted wastewater (Raschid-Sally \& Jayakody, 2008; Kapungwe, 2011, 2013). The use of wastewater to irrigate crops at the two study sites confirmed the findings from the studies in Zambia (Kapungwe, 2011, 2012; 2013; Gabi \& Simwinga, 1982) and other developing countries such as India (Bradford et al., 2002; 2003), Pakistan (Nazim, 2002), Nigeria (Odurukwe, 2002), Ghana (Abdul-Ghaniyu et al., 2002; Keraita et al., 2002), Senegal (Niang et al., 2002) and Burkina Faso (Ouedraogo, 2002). The results from this study indicated that crop cultivators used multiple sources of water supply to irrigated crops at the two study sites which were similar to the findings from the study on urban farmers' irrigation practices in Burkina Faso where urban farmers used several different sources of water supply in Ouagadougou and Bob-Dioulasso (Kinane et al., 2008).

This study revealed that seepage was significantly influenced by type of drainage at New Farm $\left(\chi^{2}=16.91\right.$, df $=$ $2, \mathrm{P} \leq 0.05$, two tailed) and Chilumba Gardens $\left(\chi^{2}=82.49\right.$, $\mathrm{df}=2, \mathrm{P} \leq 0.05$ two tailed). A total of $57.1 \%$ of seepage was the source of water supply on poor drained soils at New Farm while seepage (100\%) was the source of water supply on coal ash damp soils located in the Nitrogen Chemicals of Zambia disposal areas at Chilumba Gardens. From the foregoing explanation it can be argued that some of the sources of water supply at two study sites were influenced by agro-ecological factors such as drainage which confirmed the findings from the studies conducted by Parajuli (1999) on traditional farmer-managed irrigation systems in Nepal.

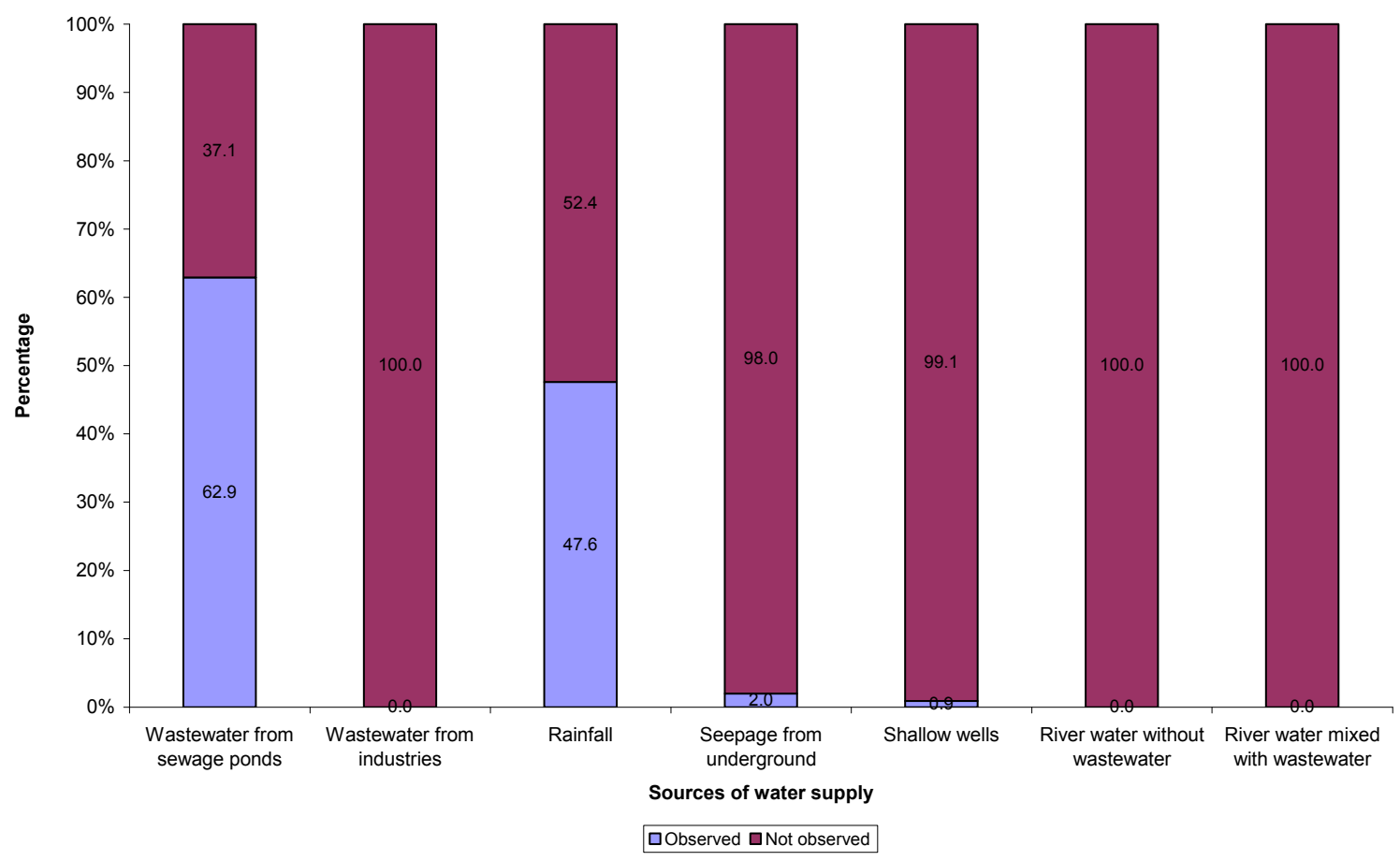

Figure 6. Sources of water supply at New Farm study site in Mufulira

Sampled for each $100 \%$ stacked column of cumulative percentages $(n=927)$

Source: Field data, 2006-2007 


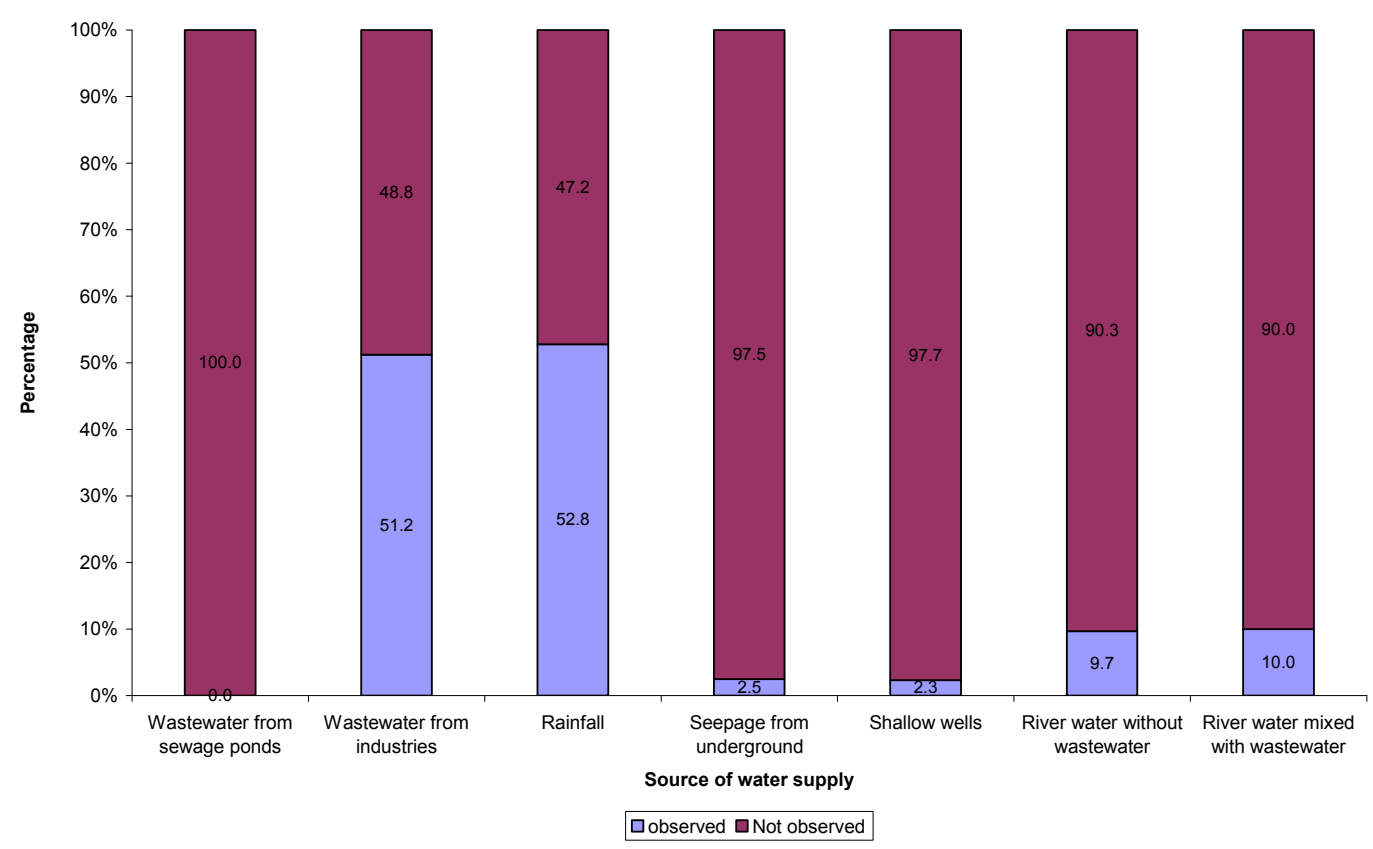

Figure 7. Sources of water supply at Chilumba Gardens in Kafue

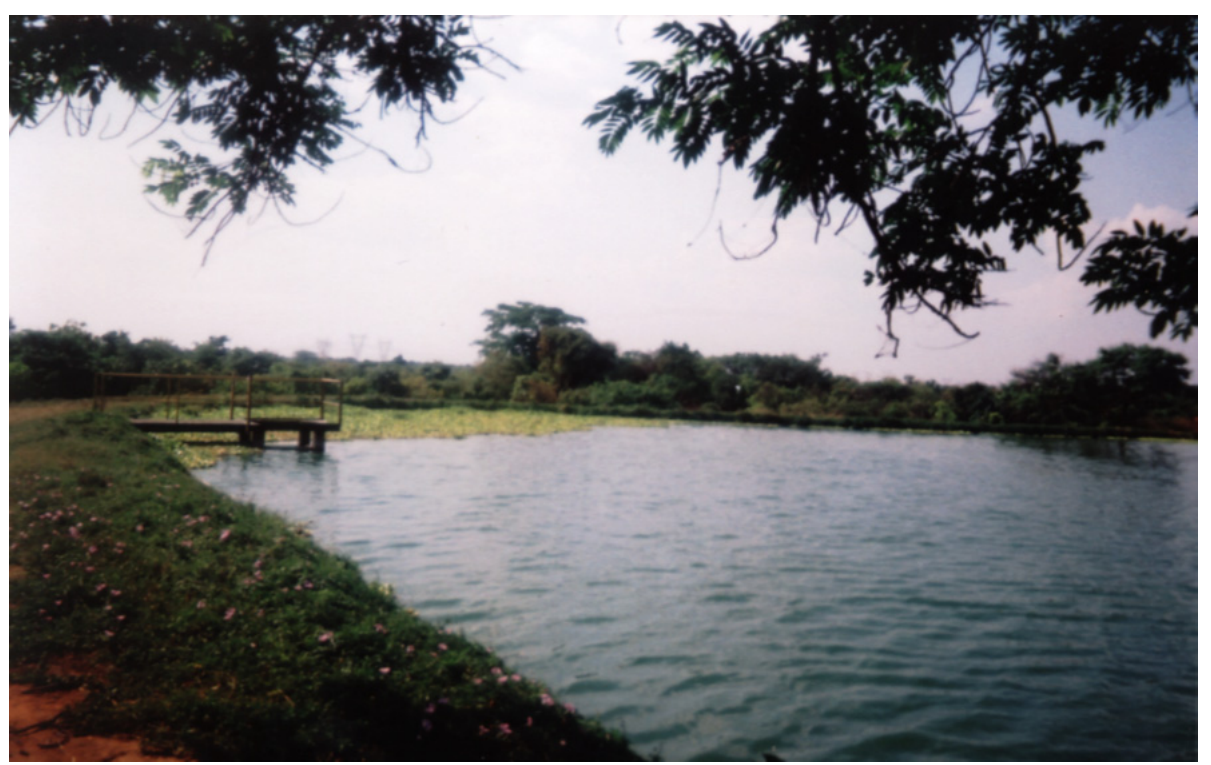

Figure 8. Kantanshi Sewerage Stabilization Pond in Mufulira 


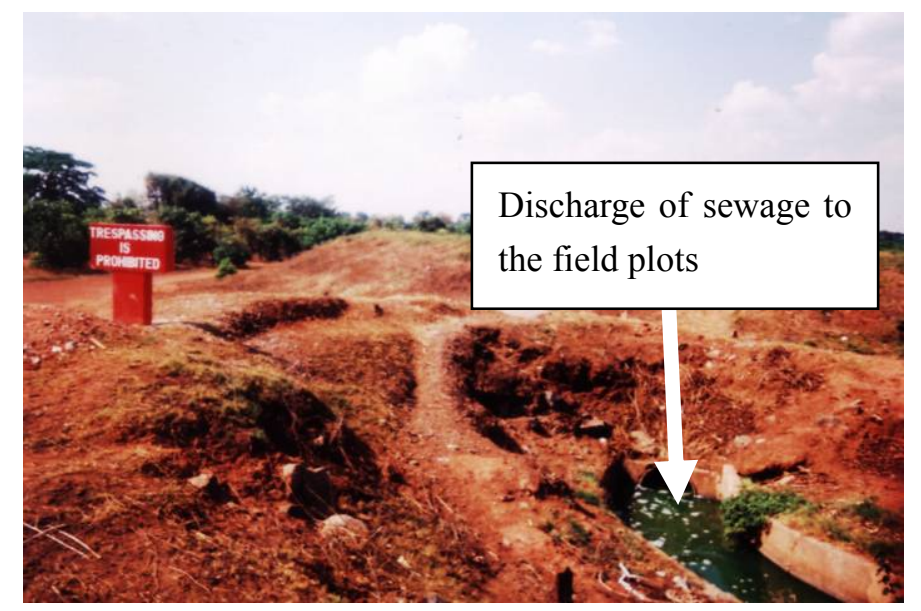

Figure 9. Kantanshi Sewage Stabilisation Pond discharge point at New Farm, Mufulira

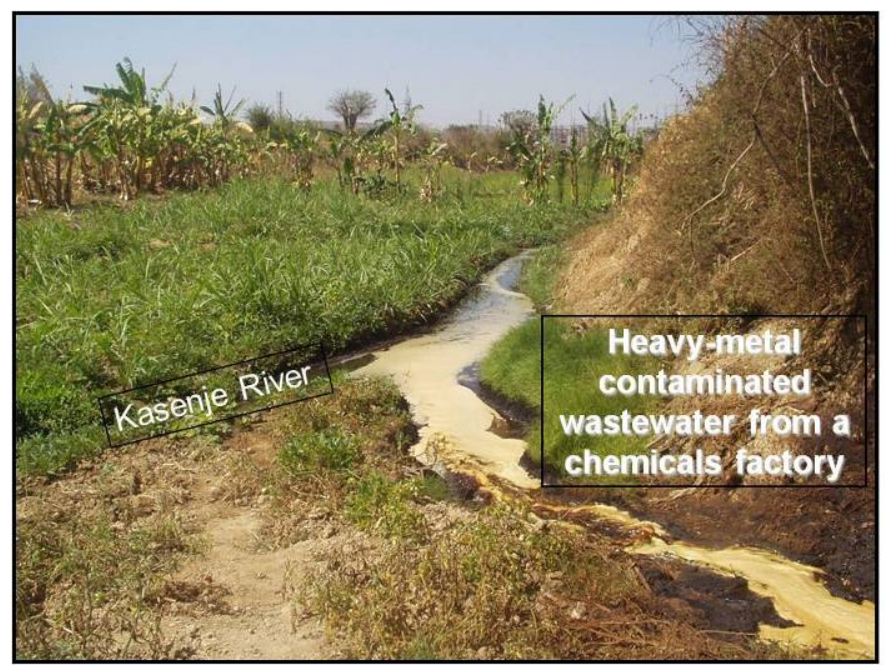

Figure 10. Lee Yeast Factory wastewater discharge point along Kasenje River in Kafue (Picture by B. Malamud)

The annual cycles of sources of water supply at the two study sites shown in Figure 11 and Figure 12 indicated multiple cycles of sources of water supply at the study sites. The Chi-square statistical tests indicated that the types of wastewater used to irrigate crops were significantly different in different seasons at New Farm $\left(\chi^{2}=\right.$ 497.82, $\mathrm{df}=2, \mathrm{P} \leq 0.05$, two tailed) and Chilumba Gardens $\left(\chi^{2}=920.72, \mathrm{df}=2, \mathrm{P} \leq 0.05\right.$ two tailed $)$. At New Farm, the main source of water supply in the hot wet season $(99.8 \%)$ was rainfall, whereas the wastewater from the sewage ponds was the main source of water supply in the cool dry seasons $(91.7 \%)$ and hot dry seasons (96.8\%). At Chilumba Gardens, the main source of water supply in the hot wet season (94.9\%) was rainfall whilst the industrial wastewater was the main source of water in the cool dry season (91.4\%) and hot dry seasons $(86.3 \%)$. Other sources of water supply in dry seasons included shallow wells and seepage. This study indicated that wastewater was used dominantly in the dry seasons which was similar to the results from the study by Bradford et al. $(2002,2003)$ in wastewater irrigation in Hubli-Dharward, India where wastewater was used in dry season to 'jump start' the growing of field crops such cotton and wheat. The results from this study indicated multiple cycles of sources of water supply at the two study sites which confirmed findings from the study in Burkina Faso where urban farmers used several different sources of water supply in different seasons in Ouagadougou and Bob-Dioulasso (Kinane et al., 2008). 

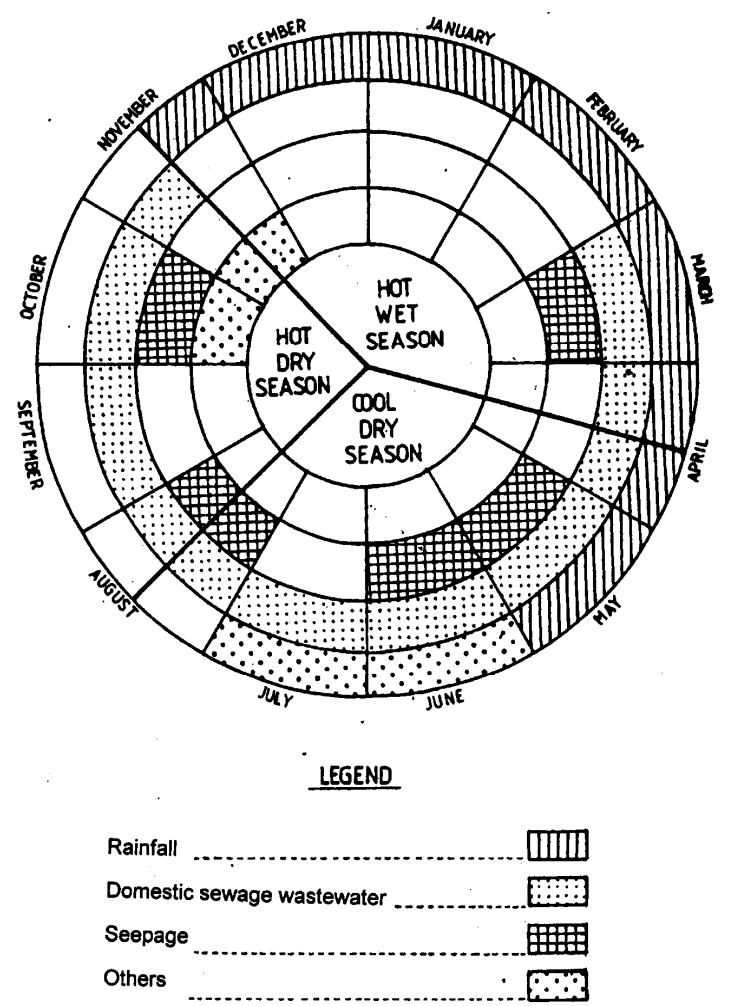

Figure 11. Annual cycle of sources of water supply at New Farm, Mufulira Source: Field data, 2006; 2007.
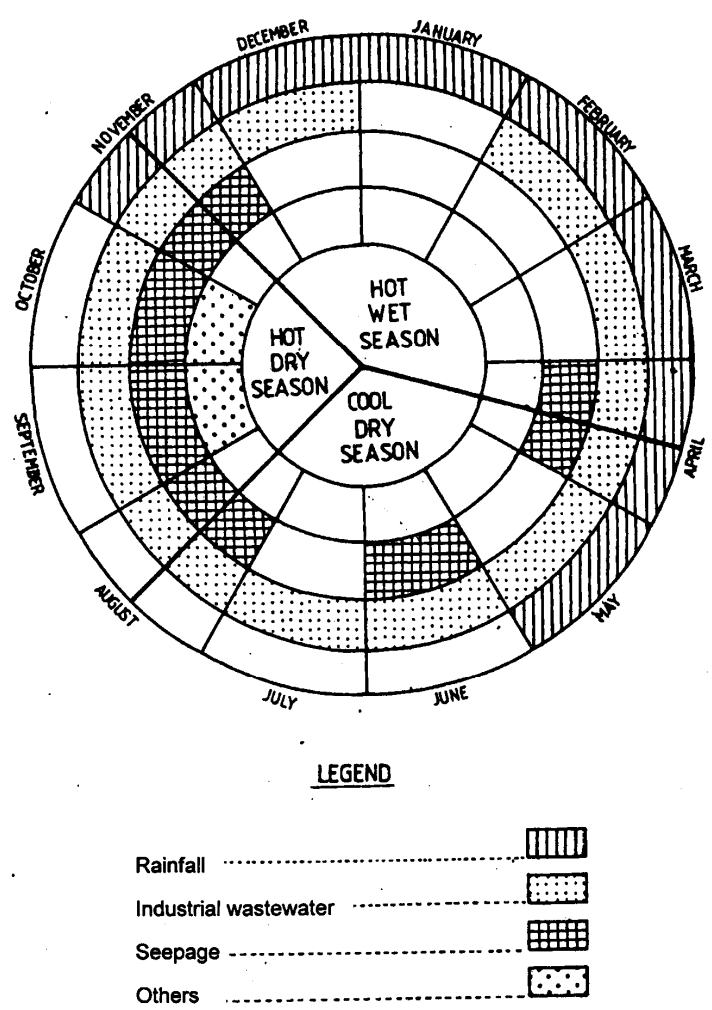

Figure 12. Annual cycle of sources of water supply at Chilumba Gardens, Kafue Source: Field data, 2006, 2007. 
The results on the methods of irrigation at the two study sites shown in Figure 13 and Figure 14 indicated multiple methods of irrigation which comprised furrows (Figure 15), river channels (Figure 16), bucket and splash. The methods of irrigation differed significantly at study sites $\left(\chi^{2}=16.56, \mathrm{df}=1, \mathrm{P} \leq 0.05\right)$. The furrows $(61.5 \%)$ were dominantly used to irrigate crops at New Farm while the furrows $(48.3 \%)$ were augmented with river channels $(2.3 \%)$ at Chilumba Gardens. Occasionally the buckets and plastic containers were used to scoop water from the shallow wells and water was splashed on crops in the field plots. The buckets were dominantly used to irrigate crops at Chilumba Gardens $(23.7 \%)$ as compared to New Farm $(0.4 \%)$. The probable reasons for multiple methods of irrigation at the two study sites include:

i. insurance against failure of certain irrigation methods such as collapse of walls of furrows

ii. physical land characteristics differences such that gentle slopes facilitated furrows because water flowed under gravity and natural movement (Bradford et al., 2003).

iii. adaptation of indigenous technology based on labour intensive, low technology because of inadequate technical support from relevant authorities (Parajuli, 1999; Ali, 2002).

The crop cultivators dominantly used surface irrigation method of furrows where water flowed on ground surface which allegedly lessen the potential direct contamination of crops from pathogens. Nevertheless, the furrows were not properly sealed and allowed underground infiltration into irrigated areas and surroundings which implied that there was loss of water from the furrows into ground which allegedly created artificially shortage of water especially during the dry seasons which confirmed that infrastructure in farmer managed irrigation systems in wastewater irrigation farming at the two study sites did not entirely conform to the standard technical hydraulic structure engineering designs (Parajuli, 1999; Ali, 2002). The use of furrows and river channels were similar to findings in the study on wastewater irrigation farming in Hubli-Dharwad, India (Bradford et al., 2003) and in Ouagadougou and Bobo-Dioulassso, Burkina Faso (Kinane et al., 2008). The buckets and plastic containers which were used to ferry water from shallow wells and dugouts to irrigate crops through splashing of water over crops can be compared to watering cans used in irrigation of crops in Kumasi, Ghana (Keriata et al., 2002; 2003); Ouagadougou and Bobo-Dioulassso in Burkina Faso (Kinane et al., 2008). The results from this study indicated that crop cultivators used multiple methods of irrigation of crops at the two study sites which was similar to the findings from the studies in other developing countries such as Burkina Faso(Kinane et al., 2008), Ghana (Keriata et al., 2002; 2003) and India (Bradford et al., 2003).

The furrow method of irrigation was significantly influenced by the types of slopes at Chilumba Gardens $\left(\chi^{2}=\right.$ $85.24, \mathrm{df}=2, \mathrm{P} \leq 0.05$ two tailed). The furrow (76.4\%) method of irrigation was dominant on gentle slopes at Chilumba Gardens which implied that the wastewater flow was aided by gravity and gentle slope gradients because the water did not have the natural movement to overcome steep slope gradients. The crop cultivators at the two study sites irrigated crops by allowing the wastewater flow under gravity along furrows and river channels to field plots assisted by slope gradient and natural movement which were similar to methods used by the crop cultivators engaged in wastewater irrigation farming in Hubli-Dharwad in India (Bradford et al., 2003), traditional farmer managed irrigation systems in Nepal (Parajuli, 1999) and traditional irrigation practices developed in flood prone basins in Vaishali District, Bihar of Eastern India (Saran et al., 1982).

Furthermore, the types of drainage significantly influenced the furrow method of irrigation at New Farm, Mufulira $\left(\chi^{2}=14.50, \mathrm{df}=2, \mathrm{P} \leq 0.05\right.$, two tailed) The furrow was the dominant method of irrigation in good $(100 \%)$ and moderate $(95.8 \%)$ drainage as compared to poor drainage $(37.5 \%)$ at New Farm. From the foregoing explanation, it can be argued that some methods of irrigation were influenced by agro-ecological factors such as slope and drainage which was similar to findings from the study on indigenous irrigation system in Nepal where the agro ecological conditions of the local areas influenced the methods of irrigation used by the local communities in traditional farmer managed irrigation system (Parajuli, 1999). 


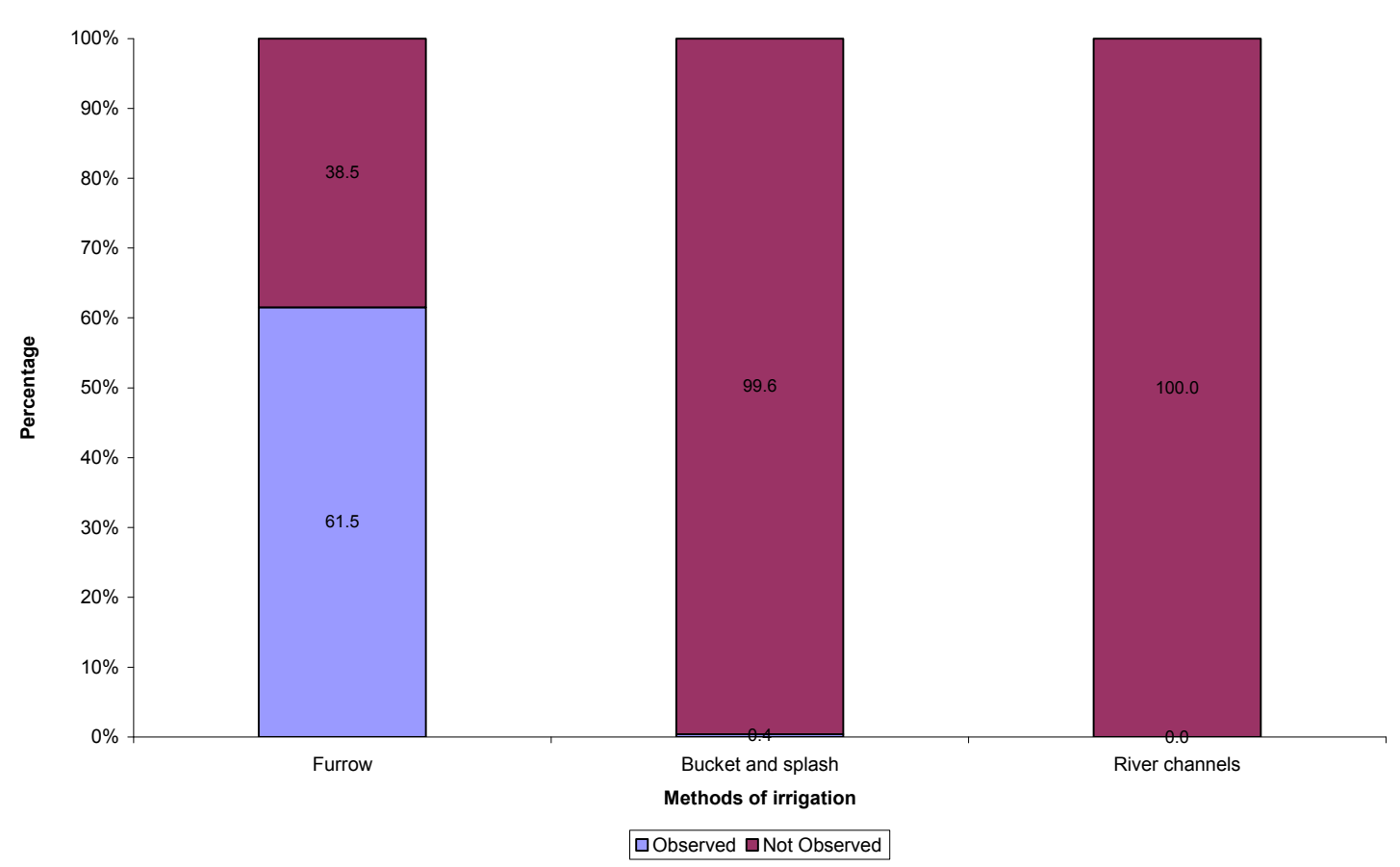

Figure 13. Methods of irrigation at New Farm study site in Mufulira

Sampled for each $100 \%$ stacked column of cumulative percentages $(\mathrm{n}=927)$

Source: Field data, 2006-2007.

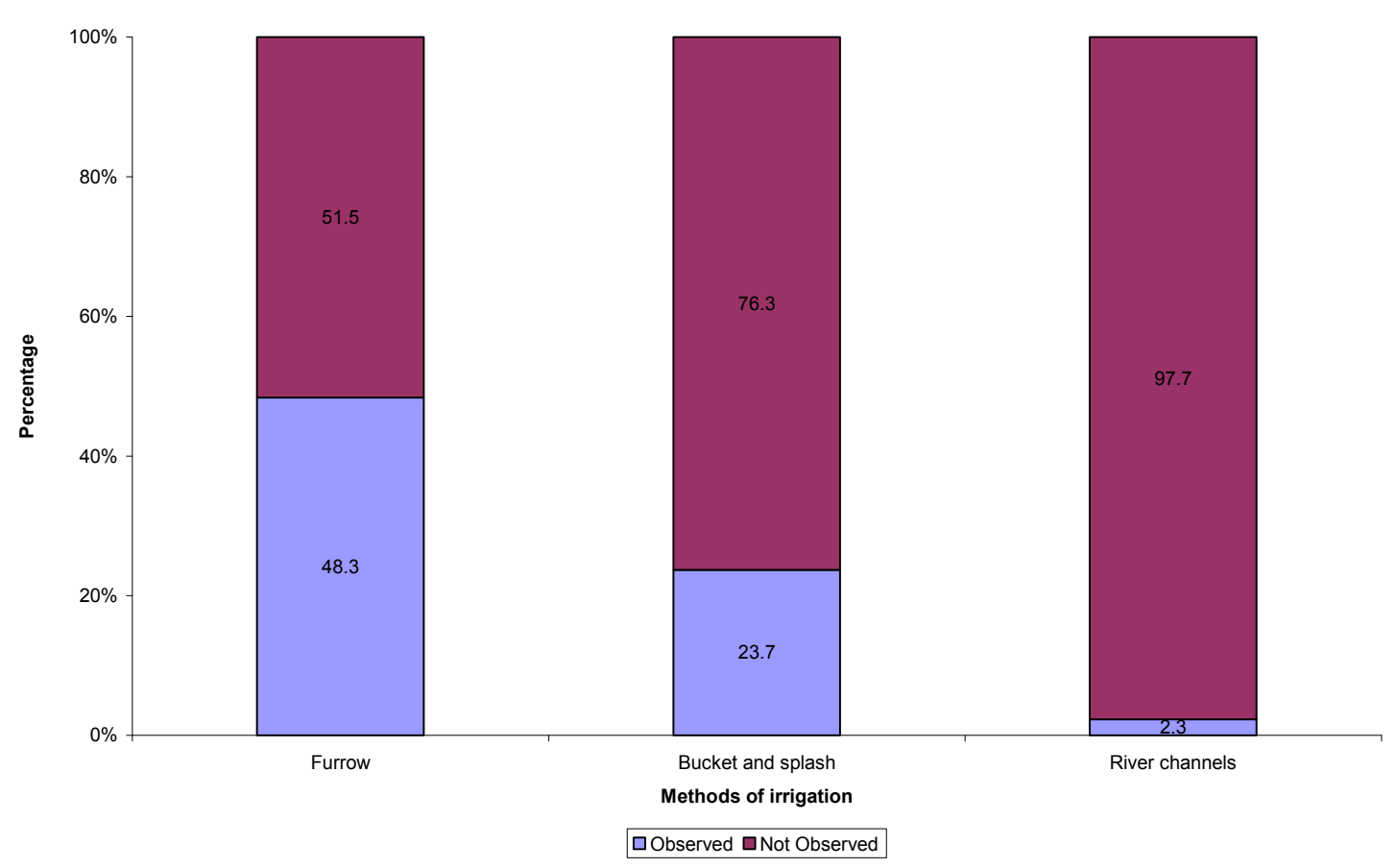

Figure 14. Methods of irrigation at Chilumba Gardens in Kafue

Sampled for each $100 \%$ stacked column of cumulative percentages $(n=1491)$

Source: Field data, 2006-2007. 


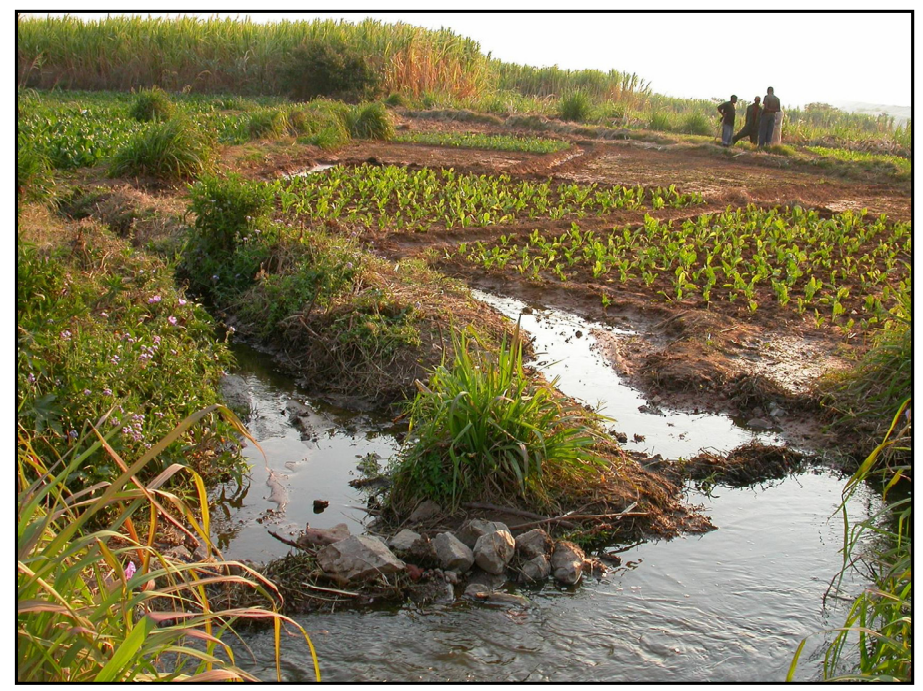

Figure 15. Surface irrigation using the irrigation furrow at New Farm, Mufulira (Picture by B. Malamud)

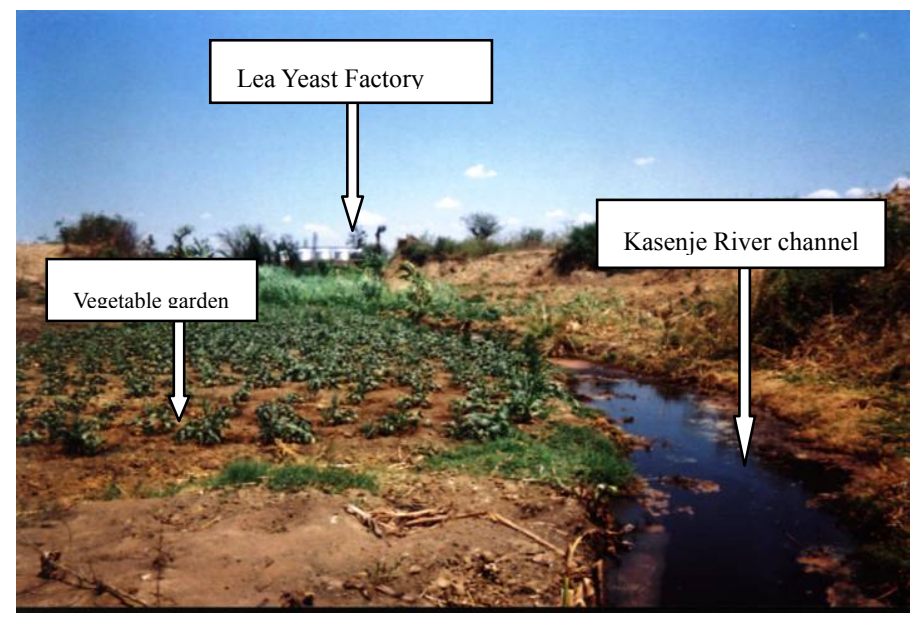

Figure 16. Kasenje River channel mixed with wastewater from Lee Yeast factory in the background at Chilumba Gardens in Kafue

The annual cycles on methods of irrigation at the two study sites shown in Table 8 indicated multiple cycles of methods of irrigation at the study sites. The Chi square tests indicated that seasonal variations significantly influenced furrow method of irrigation at New Farm $\left(\chi^{2}=504.03\right.$, df $=2, \mathrm{P} \leq 0.05$, two tailed $)$ and Chilumba Gardens $\left(\chi^{2}=780.26, \mathrm{df}=2, \mathrm{P} \leq 0.05\right.$ two tailed). The furrows were dominantly used in the cool dry season $(92.3 \%)$ and hot dry season $(96.8 \%)$ at New Farm while the furrows were dominantly used in the cool dry season $(91.4 \%)$ and hot dry season $(86.3 \%)$ at Chilumba. Other methods of irrigation in the dry season included river channels, bucket and splash. The implication of the results was that there were temporal variations in the methods of irrigation at the two peri urban areas in Zambia. The results from this study indicated multiple cycles of irrigation methods at the two study sites which confirmed the findings from the studies on wastewater irrigation farming in Ouagadougou and Bobo-Dioulassso, Burkina Faso (Kinane et al., 2008) and Ghana (Obuobie et al., 2006). 
Table 8. Annual cycles of methods of irrigation at two study sites

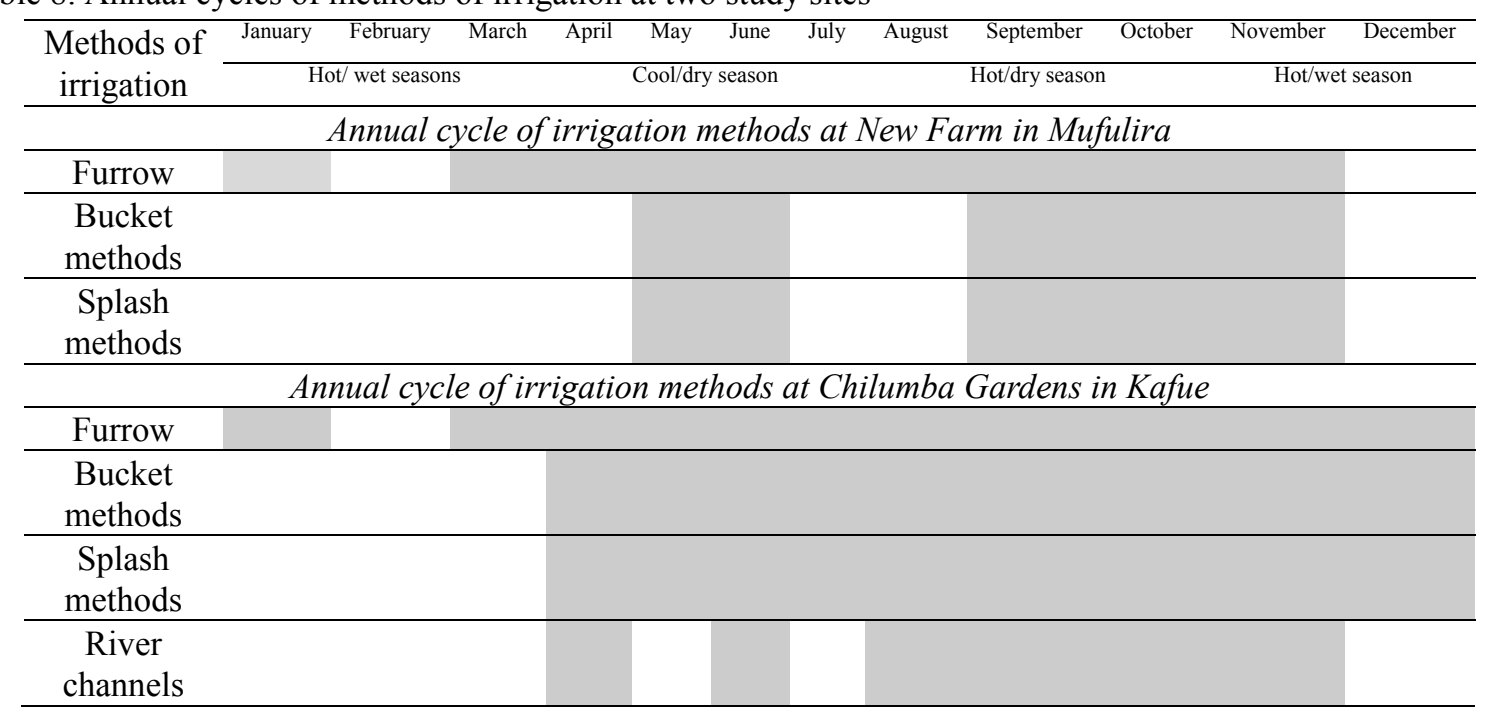

Source: Field data, 2006-2007.

\subsection{High Crop Diversification}

The results on the types of crops grown at the two study sites shown in Figure 17 and Figure 18 indicated a relatively high number of crops per study site with a total of twenty (20) types of crops grown per study site. The types of crops grown at the two study sites comprised the field crops and vegetables. The field crops included sugarcane (Figure 19) and maize (Figure 20). The vegetables (Figure 21) included indigenous (Schipper, 2000) and exotic. The indigenous crops included pumpkins, beans and cowpeas whilst the exotic crops included rape, Chinese cabbage, Swiss chard and tomatoes. In most cases the maize and vegetables were interspaced with sugarcane in the field plots (Figure 22). The sugarcane was grown abundantly at the two study sites with a total of $83.8 \%$ recorded at New Farm and a total of $81.0 \%$ recorded at Chilumba Gardens. There were significant differences in the relative abundance of maize at study sites $\left(\chi^{2}=207.75, \mathrm{df}=1, \mathrm{P} \leq 0.05\right.$, two tailed). The maize was grown abundantly at Chilumba gardens (28.8\%) as compared to New Farm (5.4\%). The Chi square statistical test indicated significant differences in the relative abundance of pumpkin grown at the study sites $\left(\chi^{2}\right.$ $=157.85, \mathrm{df}=1, \mathrm{P} \leq 0.05$, two tailed). The pumpkin was abundantly grown at Chilumba Gardens $(30.7 \%)$ as compared to New Farm (9.4\%). Furthermore, the Chi square test indicated significant differences in the relative abundance of rape grown at the study sites $\left(\chi^{2}=52.88\right.$, df $=1, \mathrm{P} \leq 0.05$, two tailed). The rape was grown abundantly at Chilumba Gardens (16.6\%) as compared to New Farm (6.8\%). The mustard spinach (1.0\%) was grown only at Chilumba Gardens. The results indicated that there were significant differences in the relative abundance of crops grown at the study sites. Furthermore, some crops were contaminated with heavy metals because the crops were mainly irrigated with treated domestic wastewater and untreated effluents contaminated with heavy metals (Kapungwe, 2011, 2012, 2013) Thus, there was likelihood of the potential health risk associated with consumption of crops contaminated with heavy metals (Kapungwe, 2011, 2013).

The results on the numbers of crops per field plot at the two study sites shown in Table 9 indicated a relatively high number of crops per field plot (Table 9). The number of crops per field plot were significantly different at the two study sites $\left(\chi^{2}=228.201, \mathrm{df}=7, \mathrm{p}<0.05\right.$, two tailed). An average of $1.47 \pm 0.00$ crops per field plot was recorded at New Farm with the range of minimum of one crop per field plot to a maximum ten crops per field plot. An average of $1.88 \pm 0.00$ crops per field plot was recorded at Chilumba Gardens with the range of minimum of one crop per field plot to a maximum seven crops per field plot. The results indicated relatively high number of crops per field plot at Chilumba Gardens while there was relatively low number of crops per field plot at New Farm. 
Table 9. Number of types of crops per field plot at study sites

\begin{tabular}{ccccc}
\hline \multirow{2}{*}{$\begin{array}{c}\text { Number of types } \\
\text { of crops per field }\end{array}$} & \multicolumn{2}{c}{ New Farm } & \multicolumn{2}{c}{ Chilumba Gardens } \\
\cline { 2 - 5 } plot & No. & Percentage & No. & Percentage \\
\hline One crop & 745 & 77.8 & 881 & 49.6 \\
Two crops & 89 & 9.3 & 459 & 25.8 \\
Three crops & 59 & 6.2 & 282 & 15.9 \\
Four crops & 37 & 3.9 & 97 & 5.5 \\
Five crops & 14 & 1.5 & 47 & 2.6 \\
Six crops & 9 & 0.9 & 10 & 0.6 \\
Seven crops & 4 & 0.4 & 2 & 0.1 \\
Ten crops & 1 & 0.1 & 0 & 0 \\
Total: & 958 & 100.0 & 1778 & 100.0 \\
\hline
\end{tabular}

Source: Field data, 2006-2007.

The high number of types of crops per study site and the high number of types of crops per field plot indicated high crop diversification at the New Farm and Chilumba Gardens. The probable reasons for high diversification of crops include:

i. insurance against unforeseen circumstances such as land tenure insecurity and uncertainty in market prices (Kinane et al., 2008; Kapungwe, 2012).

ii. reduced labour cost of crop production as the cost of cultivation is spread among the different crops grown in wastewater irrigated areas (Obuobie et al., 2006; Kapungwe, 2012).

iii. high returns on crops per field plots because some crops such as sugarcane are sold at higher market prices while other crops vegetables where either sold to generate income or consumed members of household of crop cultivators (Pasquini et al., 2009; Kapungwe, 2012).

iv. spread the risks of food crops contamination with heavy metals because plants differ considerably in their ability to absorb heavy metals (Kapungwe, 2011; 2013).

v. readily available water throughout the year (Kapungwe, 2011;2012; 2013).

The high diversity of crops grown at the study sites confirmed findings from previous studies on wastewater irrigation farming in Zambia (Kapungwe, 2011, 2012, 2013) and India (Bradford et al., 2003). Furthermore, the high crop diversification at the study sites was similar to multiple species gardens practiced by indigenous people under traditional farming systems and wastewater irrigation farming in developing countries. According to the study conducted in Mexico the indigenous people grew a variety of crops comprising field crops such as maize, wheat and vegetables such as beans (Losada et al., 1998). In sub Saharan Africa, the Medge people of Zaire (DRC) were known to grow 80 varieties of 30 species of food crops where as more than 50 species are grown in Eastern Nigeria as compared to 156 crops grown in Hausa land in Northern Nigeria (Wood, 1984). Some of the crops grown at the two study sites were similar to crop grown under small scale rural traditional Chitemene (slash and burn) farming system practiced among the Bemba, Lala and Lamba people in Zambia (Thomson, 1968; Prichard, 1994) which included maize, sorghum, sweet potatoes and groundnuts. The results indicated that the local urban farmers adapted the rural crop traditional farming systems' practices to peri urban wastewater irrigation farming systems.

At New Farm, the nature of slope significantly influenced groundnuts $\left(\chi^{2}=40.87, \mathrm{df}=1, \mathrm{P}<0.05\right.$, two tailed $)$ while the Chinese cabbage was significantly influenced by type of soils $\left(\chi^{2}=5.38, \mathrm{df}=1, \mathrm{P} \leq 0.05\right.$, two tailed). The groundnuts were dominantly grown on gentle slopes $(100 \%)$ as compared to steep slopes $(2.2 \%)$ while Chinese cabbage were dominantly grown on clay loam soil (15.9\%) as compared to laterite (2.1\%) at New Farm. At Chilumba Gardens, the type of soil significantly influenced the pumpkin $\left(\chi^{2}=14.51, \mathrm{df}=3, \mathrm{P} \leq 0.05\right.$, two tailed) and rape $\left(\chi^{2}=14.51, \mathrm{df}=3, \mathrm{P} \leq 0.05\right.$, two tailed). A total of $22.0 \%$ of pumpkins were grown on clay loam soils while a total of $32.0 \%$ of rape was grown on clay loam soil at Chilumba Gardens. The results indicated that the types of crops grown at the two study sites were influenced by the combination of agro-ecological factors with the overriding factor being type of soils which confirmed the findings from the studies in Zambia (Allan, 1969) and India (Bradford et al., 2003). The cultivation of sorghum as a staple food imposed a certain measure of selection of soil types in the traditional farming system practiced by the Lamba people in Zambia (Allan, 1969) while type of soil influenced the types of crops grown in the wastewater irrigation farming in Hubli-Dharwad, 
India (Bradford et al., 2003).

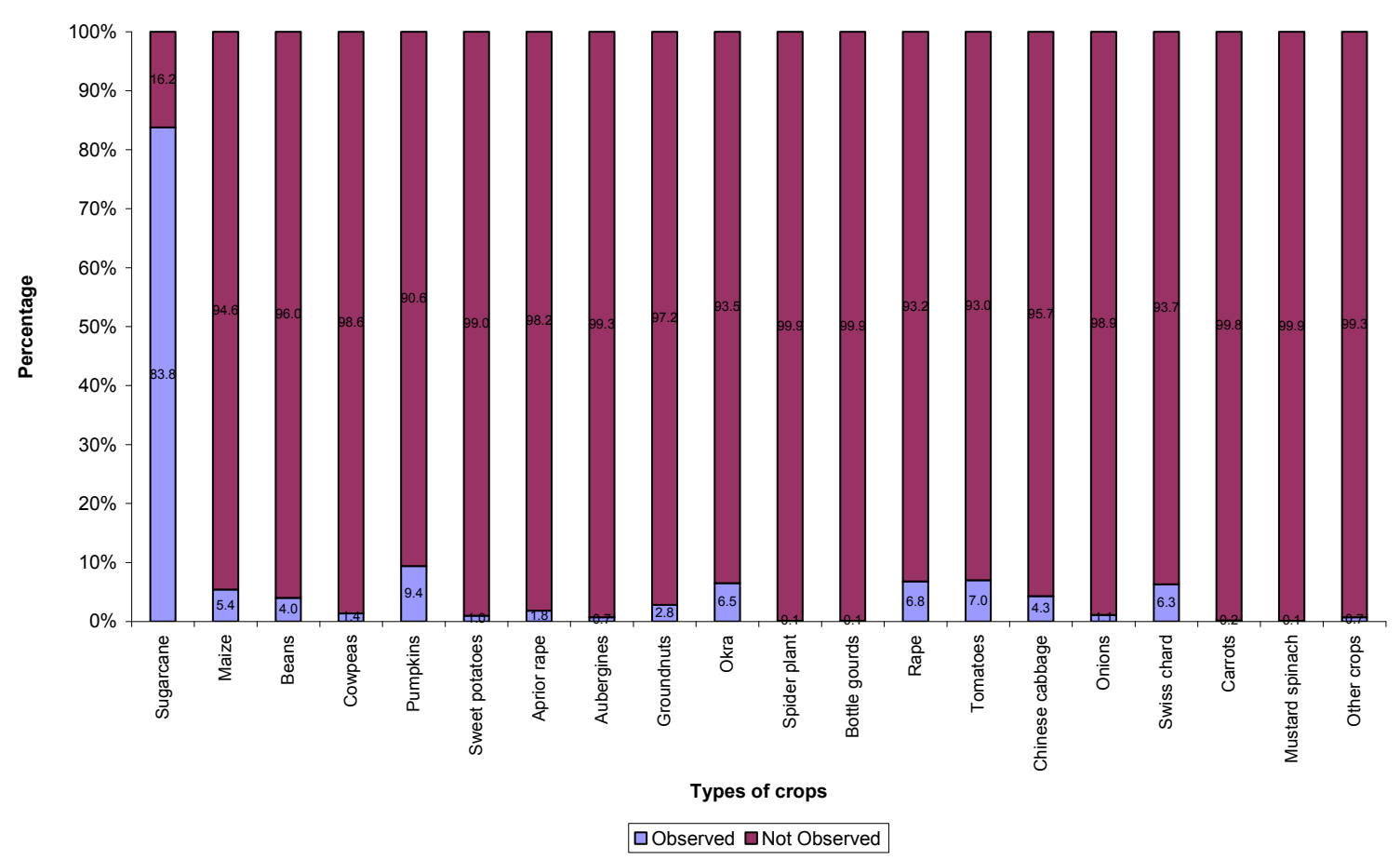

Figure 17. Type of crops grown at New Farm study site in Mufulira

Sampled for each $100 \%$ stacked column of cumulative percentages $(n=958)$.

Source: Field data, 2006-2007.

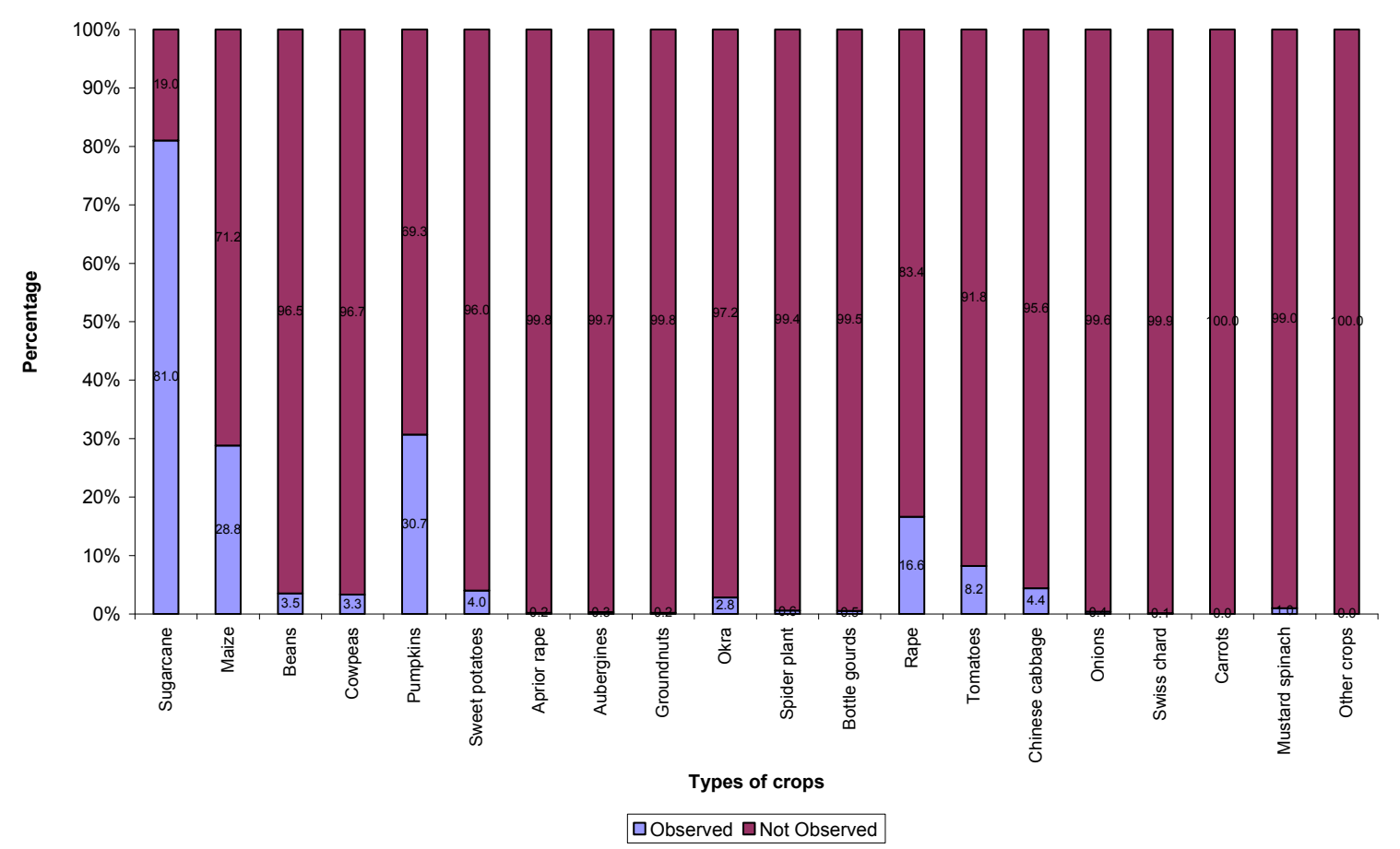

Figure 18. Type of crops grown at Chilumba Gardens in Kafue

Sampled for each $100 \%$ stacked column of cumulative percentages $(n=1778)$

Source: Field data, 2006-2007. 


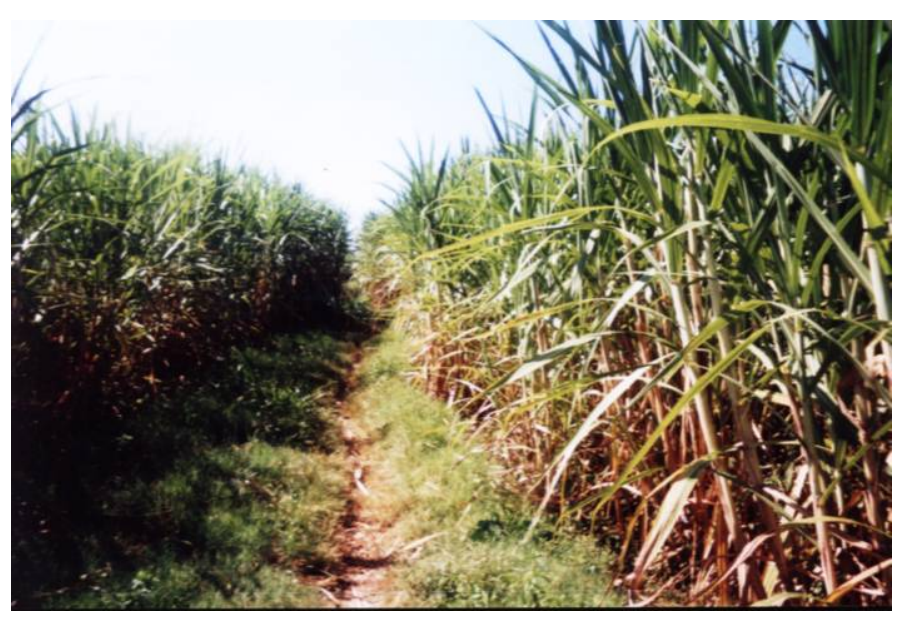

Figure 19. Sugarcane grown at New Farm in Mufulira

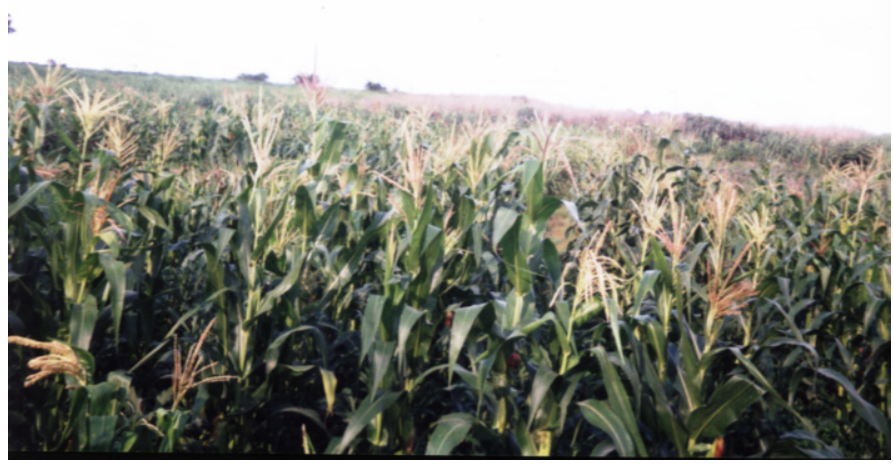

Figure 20. Maize grown at New Farm in Mufulira

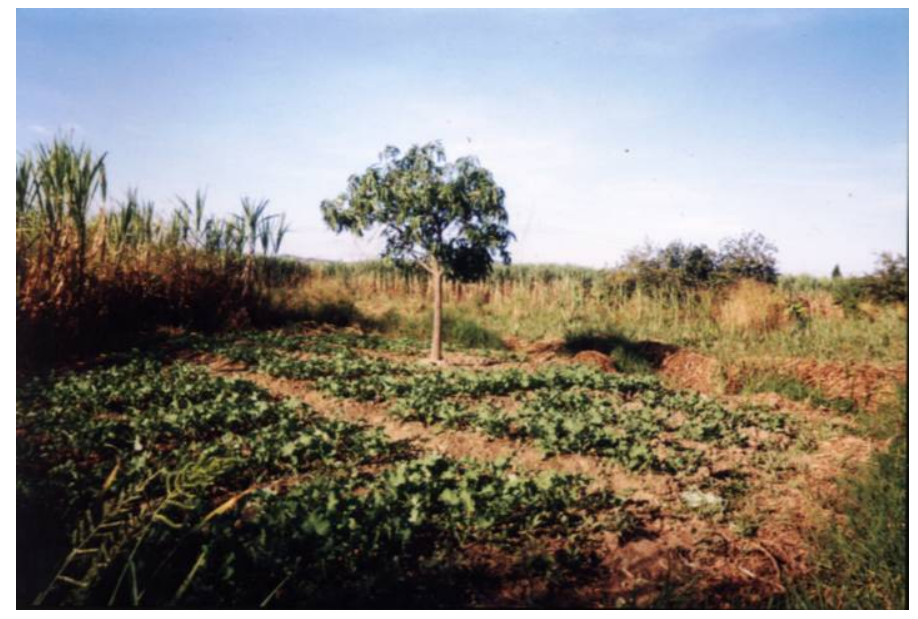

Figure 21. Vegetable grown at Chilumba Gardens in Kafue 


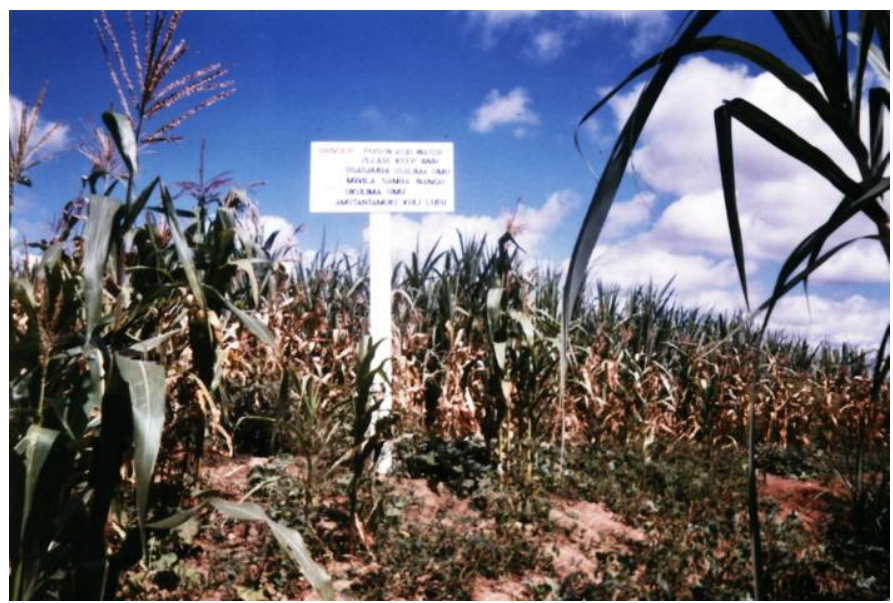

Figure 22. Sugarcane-maize-vegetable grown at Chilumba Gardens in Kafue

The annual cycles of the crops grown at the two study sites shown in Table 10 and Table 11 revealed that different crops were grown in different seasons of the year. There were significant associations between seasons and okra at New Farm $\left(\chi^{2}=30.66, \mathrm{df}=2, \mathrm{P} \leq 0.05\right.$, two tailed $)$ and maize at Chilumba Gardens $\left(\chi^{2}=338.90\right.$, $\mathrm{df}$ $=2, \mathrm{P} \leq 0.05$, two tailed). The okra was dominantly grown in the hot wet season (11.8\%) as compared to cool dry seasons $(2.0 \%)$ and hot dry season $(3.9 \%)$ at New Farm while the maize was dominant in the hot wet season $(51.6 \%)$ as compared to cool dry season $(11.4 \%)$ and hot dry season $(11.8 \%)$. The Chi square test indicated that there was a significant association between rape and seasons at New Farm $\left(\chi^{2}=45.04, \mathrm{df}=2, \mathrm{P} \leq 0.05\right.$, two tailed) and Chilumba Gardens $\left(\chi^{2}=136.42, \mathrm{df}=2, \mathrm{P} \leq 0.05\right.$, two tailed $)$. The rape was dominant in the cool dry season $(13.4 \%)$ and hot dry season $(7.5 \%)$ as compared to hot wet season $(0.8 \%)$ at New Farm, while the rape was dominant in the cool dry season (22.5\%) and hot dry season (27.7\%) as compared to hot wet season (5.0\%) at Chilumba Gardens. The results indicated that seasons influenced the types of crops grown at the study sites.

This study revealed mixing of crops in different cycles in the wastewater irrigation farming system at the two study sites which entailed that the vegetables with short growing-cycle and field crops with long growing-cycle were grown simultaneously (Pasquini et al., 2009). This study indicated multiple cycles of crops grown at study sites which confirmed findings from studies on wastewater irrigation farming in Zambia (Kapungwe, 2011, 2012, 2013) and other developing countries (Pasquini et al., 2009; Raschid-Sally \& Jayakody, 2008; Obuobie et al., 2006; Kinane et al., 2008). Furthermore, the multiple cycles of crops grown at two study sites were similar to findings on urban crop agricultural cycles on termitaria gardening in Lusaka City, Zambia (Jaeger \& Huckabay, 1986) where planting of maize, pumpkin and beans was done from November to late February and harvesting of pumpkin leaves, bean leaves, maize, pumpkin and beans was done from mid February to mid May.

Table 10. Annual cycle of crops grown at New Farm, Mufulira

\begin{tabular}{|c|c|c|c|c|c|c|c|c|c|c|c|c|}
\hline \multirow{2}{*}{$\begin{array}{c}\text { Types of } \\
\text { crops } \\
(\mathrm{n}=1111)\end{array}$} & November & December & January & February & March & April & May & June & July & August & September & October \\
\hline & \multicolumn{5}{|c|}{ Hot/ wet season } & \multicolumn{4}{|c|}{ Cool/dry season } & \multicolumn{3}{|c|}{ Hot /dry season } \\
\hline \multicolumn{13}{|l|}{ Sugarcane } \\
\hline \multicolumn{13}{|l|}{ Maize } \\
\hline \multicolumn{13}{|l|}{ Beans } \\
\hline \multicolumn{13}{|l|}{ Cowpeas } \\
\hline \multicolumn{13}{|l|}{ Rape } \\
\hline \multicolumn{13}{|l|}{ Pumpkins } \\
\hline \multicolumn{13}{|l|}{ Tomatoes } \\
\hline \multicolumn{13}{|l|}{ Okra } \\
\hline \multicolumn{13}{|l|}{$\begin{array}{c}\text { Sweet } \\
\text { potatoes }\end{array}$} \\
\hline \multicolumn{13}{|l|}{$\begin{array}{l}\text { Chinese } \\
\text { cabbage }\end{array}$} \\
\hline Cabbage & & & & & & & & & & & & \\
\hline
\end{tabular}




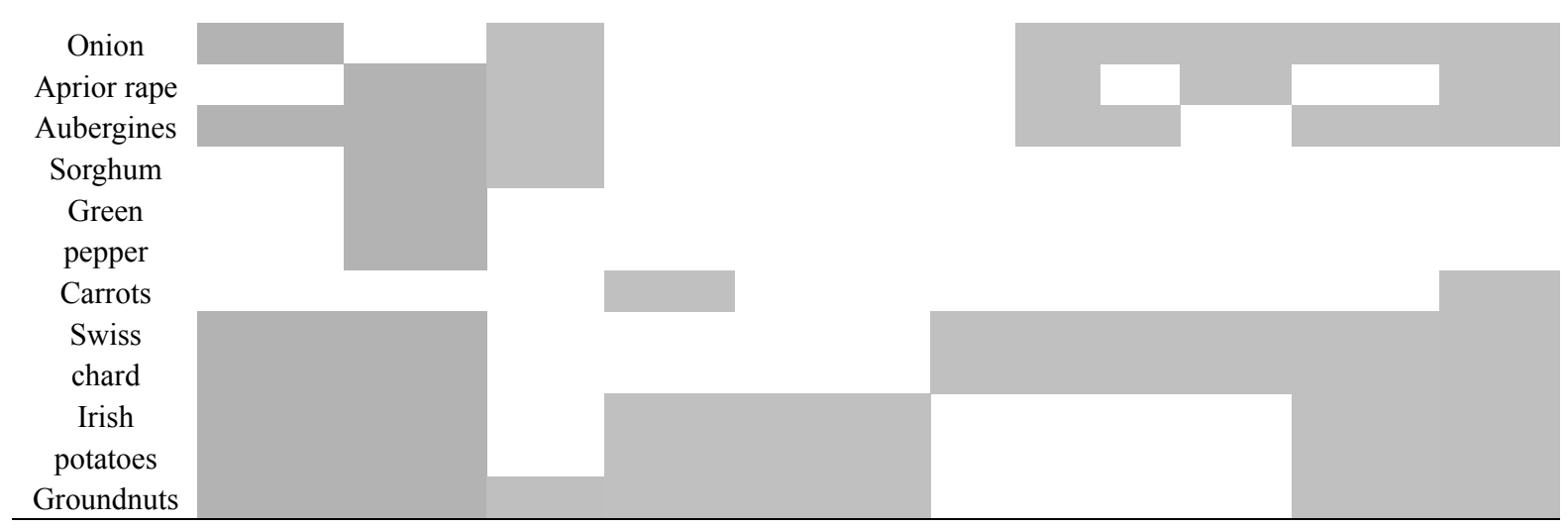

Source: Field data, 2006, 2007.

Table 11. Annual cycle of crops grown at Chilumba Gardens, Kafue

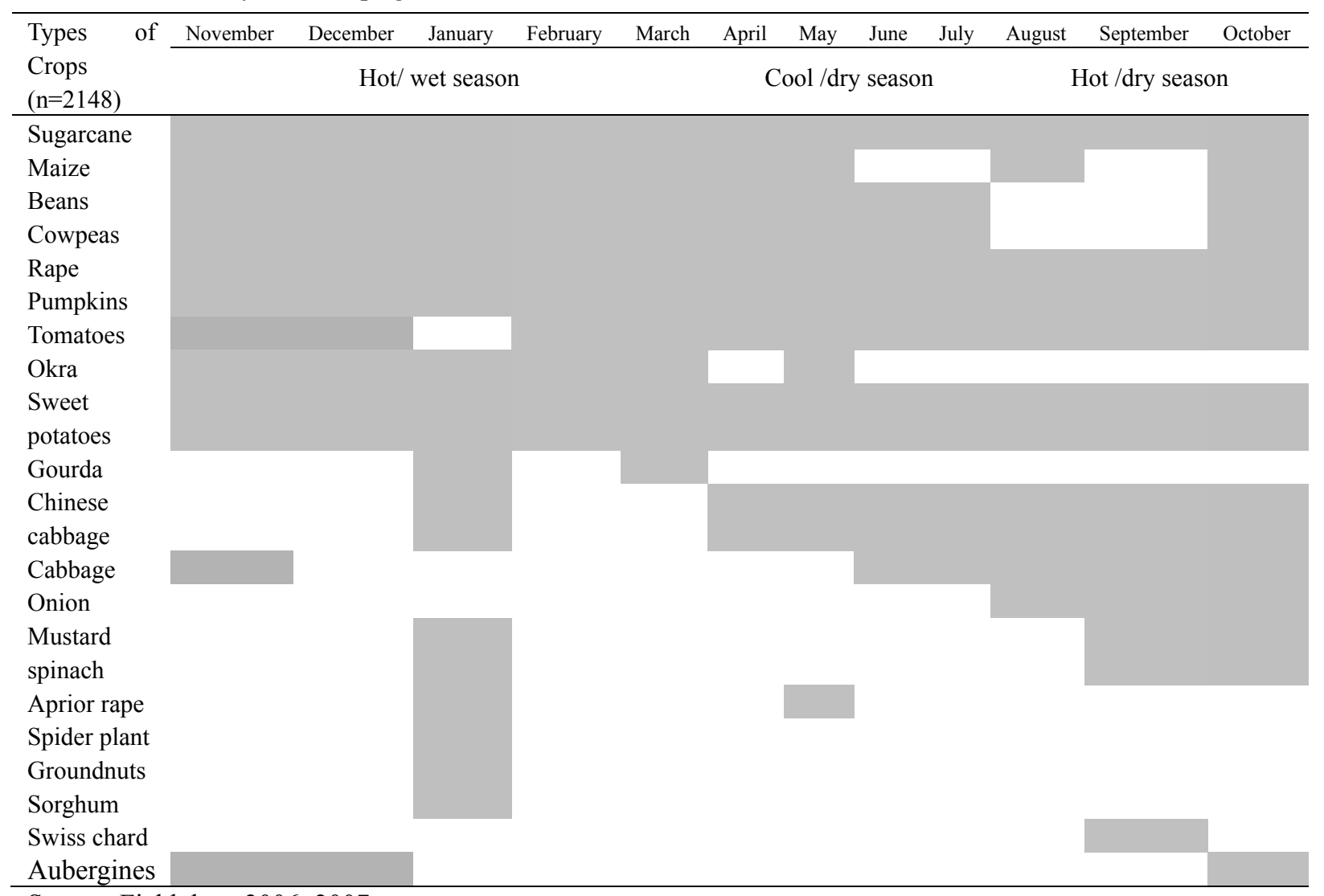

Source: Field data, 2006, 2007.

\section{Conclusions}

The farmer managed irrigation systems at the two study sites were characterised by multiple sources of water supply, multiple methods of irrigation, relatively high number of crops per study site; relatively high number of crops per field plot, multiple cycles of irrigation practices and multiple cycles of crops. The irrigation practices and types of crops were influenced by a combination agroecological factors such as slope, soils and drainage. In conclusion, the farmer managed irrigation systems at the two peri urban areas were characterised by traditional multiple irrigation practices, high crop diversification and multiple cycles of agricultural practices which were typical of traditional farmer managed irrigation systems. It can be argued that the crop cultivators have adapted the rural traditional irrigation systems' farming practices to the peri urban wastewater irrigation systems in Zambia which confirmed the findings from other developing countries. The information from this study will be used to select and implement appropriate agricultural practices which can mitigate the negative effects of heavy 
metal contamination.

\section{Acknowledgement}

The DFID UK project R8160 provided the funds to facilitate data collection. Mr. Joseph. Chalila the Chief Cartographer and Ms Alice Nguluwe, the Assistant cartographer of the Geography Department assisted in the drawing of the maps. The study leave granted to the author by Staff Development Office of the University of Zambia facilitated the collection of data during the research.

\section{References}

Ali, N. (2002),Economic and institutional issues of wastewater use in Faisalabad, Pakistan. Urban Agriculture Magazine, 8, 26-28.

Allan, W. (1969). Studies in African land usage in Northern Rhodesia The Rhodes-Livingstone papers, Number 15. Manchester: University of Manchester .

Ayers, R.S., and Westcot, D.W. 1985. Water Quality for Agriculture. Rome: Food and Agriculture Organisation.

Bradford, A. Brook, R. and Hunshal, C.S. (2002). Crop selection and wastewater irrigation, Hubli-Dharwad, India. Urban Agriculture Magazine, 8 ,31-32.

Bradford, A. Brook, R. and Hunshal, C.S. (2003). Wastewater irrigation in Hubli-Dharwad, India: Implications for health and livelihoods. Environment and Urbanization, 8 (2),157-1170.

Buechler, S., Devi, G. and Raschid, L. (2002a).Livelihoods and wastewater irrigated agriculture: Musi River in Hyderabad City, Andhra Pradesh, India. Urban Agriculture Magazine, 8, 14-17.

Buechler, S., Hertog W. and Van Veenhuizen, R. (2002b).Wastewater use for urban agriculture. Urban Agriculture Magazine, 8, 1-4.

Cavallini, J. M. and Young, L.E. (2002).Reality and potential: Integrated systems for the treatment and recycling of wastewater in Latin America. Urban Agriculture Magazine, 8,18-19.

de Neergaard, A. Drescher, A.W., and Koume, C. (2009). Urban and Peri-urban Agriculture in Africa Cities. In: C. M. Shackleton, M. W. Pasquini and A.W. Drescher African indigenous vegetables in urban agriculture. London: Earth scan.

Drechsel, P., Cofie, O.O., Keraita, B., Amoah, P., Evans A. and Amerasinghe, P. (2011). Recovery and reuse of resources: Enhancing urban resilience in low-income countries. Urban Agriculture Magazine, 25, 66-69.

Gabi, M. and Simwinga, J. S. (1982). Future Development of Vacant Land in and around Lusaka. In: L. Van Den Berg, In the Shadow of Lusaka: Land and People under Pressure of Urban Growth, 1-12. Studies in Zambian Society Number 6. Lusaka: University of Zambia,

Jaeger D. and Huckabay, J. D. (1986). The Garden City of Lusaka: Urban Agriculture. In: G.F. Williams (Ed), Lusaka and its Environs: A Geographical Study of a Planned Capital in Tropical Africa, Zambia Geographical Association, Handbook Series No. 9, Lusaka: University of Zambia.

Kapungwe, E.M. (2011). Industrial land use and heavy metal contaminated wastewater used for irrigation in peri-urban Zambia. Singapore Journal of Tropical Geography, 32(1), 71-84. doi:10.111/j.1467-9493.2011.00422.x.

Kapungwe, E.M. (2012).Traditional farming practices and wastewater irrigation farming in peri-urban Zambia. Indonesian Journal of Geography.44 (2): 104-120

Kapungwe, E.M. (2013). Heavy metal contaminated water, soils and crops in peri urban wastewater irrigation farming in Mufulira and Kafue in, Zambia, Journal of Geography and Geology, 5 (2): 56-72. Dio: 10.5339/jgg.v5n2p55 published online April 18, 2013 (http://dx.doi.org/ jgg.v5n2p55).

Kinane, M.L., Tougma, A., Ouedraogo, D and Sonou, M, (2008). Urban Farmers' Irrigation practices in Burkina Faso. Urban Agriculture Magazine, 20, 25-26.

Losada, H., Martinez, H. Vieyra, J., Pealing, R., Zavala, R., and Cortes, J., (1998). Urban agriculture in the metropolitan zone of Mexico City: changes over time in urban, sub-urban and peri urban areas. Environment and Urbannization, 10 (2):37-54

Marshall, B., Bowyer-Bower, T., Chishala, B. H., Kapungwe, E. M., Agrawal, M., Agrawal, R., Lintelo, D., Holden, J., Macwani, M., Volk. J., Krishnan V. and Sharma, R. (2004). Contaminated irrigation water and food safety for the urban and peri-urban poor: Appropriate measures for monitoring and control from field 
research in India and Zambia. Main Inception Report. Department for International Development (DFID) project No.R8160. London: Department for International Development (DFID-UK)

Obuobie, E., Keraita, B., Danso, G., Amoah, P., Cofie, O., Raschid-Sally, L. and Drescher, P. (2006). Irrigated urban vegetable production in Ghana: characteristics, benefits and risk., Accra: International Water Management Institute.

Oluoch, M.O., Pichop, G.M., Silue, D., Abukutsa-Onyango, M.O., Diouf, M., and Shackleton, C.M., (2009). In: C. M. Shackleton, M. W. Pasquini and A.W. Drescher African indigenous vegetables in urban agriculture. London: Earth scan.

Parajuli, U.N. 1999. Agro-ecology and irrigation technology: a comparative research on Farmer-managed irrigation systems in mid-hills of Nepal. PhD. thesis. Wageningen: University of Wegenigen,

Parkinson, J. and Tayler, K. (2003). Decentralized wastewater management in peri-urban areas in low-income countries. Environment and Urbanization, 8(1), 75-89.

Pasquini, M. Assogba-Komlan, W. F., Voster, I. Shackleton, C.M. and Abukutsa-Onyango, M.O., (2009). The production of African vegetables in urban and peri urban agriculture: a comparative analysis of case studies from Benin, Kenya and South Africa, In: C. M. Shackleton, M. W. Pasquini and A.W. Drescher, African indigenous vegetables in urban agriculture. London: Earth scan.

Pritchard, J.M. (1994). Africa: A study geography for advanced students. Essex: Longman,

Raschid-Sally, L. and Jayakody, P. (2008). Drivers and characteristics of wastewater agriculture in developing countries-results from global assessment. Sockholm: International Water Management Institute (IWMI)

Saran, S. Sinha, M.M. and Kumar, A. (1998). Farming Systems Development in Flood Prone Basins. Delhi: Daya Publishing House

Schipper, R.R. (2000). Africa indigenous vegetables: an overview of the cultivated species. London: Natural resources Institute of University of Greenwich. ,

Silva-Ochoa, P. and Scott, C.A. (2002).The impact of a treatment plant on wastewater irrigation in Mexico. Urban Agriculture Magazine, 8, 33-34.

Smit J. and Nasr, J. (1992). Urban Agriculture for Sustainable Cities: using wastes and idle land and water bodies as resources. Environment and Urbanisation, 4 (2), 141-152.

Smith, M., Skinner Band Woodfield, J. (2001). Way forward: Environmental sanitation. In: R. Scott, 27th WEDC Proceedings Conference, Lusaka, Zambia. Leicestershire: University of Loughborough.

Thomson, B. P. (1968). Two studies in African Nutrition: An urban and a rural community in Northern Rhodesia. The Rhodes-Livingstone papers, Number 24. Manchester: University of Manchester,

Uphoff, N. (1986) Getting the process right: improving irrigation management with farmer organisation and participation, working paper Ithaca: Cornell University.

Wood, P. J. (1984). Mixed systems of plant production in Africa. In: D L, Hawksworth (Edit) Advancing agricultural production in Africa: proceedings of Commonwealth Agricultural Bureaux First scientific conference Arusha, Tanzania, 12-18 February 1984. Slough: Commonwealth Agricultural Bureaux.

\section{Copyrights}

Copyright for this article is retained by the author(s), with first publication rights granted to the journal.

This is an open-access article distributed under the terms and conditions of the Creative Commons Attribution license (http://creativecommons.org/licenses/by/3.0/). 